\title{
Lead isotopes behavior in the fumarolic environment of the Piton de la Fournaise volcano (Réunion Island)
}

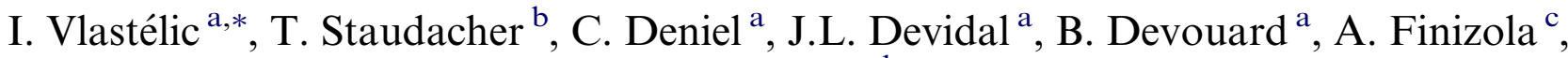 \\ P. Télouk ${ }^{\mathrm{d}}$ \\ ${ }^{a}$ Laboratoire Magmas et Volcans, Clermont Université, Université Blaise Pascal, CNRS UMR 6524, IRD R 163, France \\ ${ }^{\mathrm{b}}$ Observatoire Volcanologique du Piton de la Fournaise, Institut de Physique du Globe de Paris, Sorbonne Paris Cité, CNRS UMR 7154, France \\ ${ }^{\mathrm{c}}$ Laboratoire GéoSciences Réunion, Université de la Réunion, Institut de Physique du Globe de Paris, Sorbonne Paris Cité, CNRS UMR \\ 7154, France \\ ${ }^{\mathrm{d}}$ Laboratoire des Sciences de la Terre, Ecole Normale Supérieure de Lyon, CNRS UMR 5570, France
}

Received 6 January 2012; accepted in revised form 10 September 2012; available online 18 September 2012

\begin{abstract}
The recent activity of the Piton de la Fournaise volcano offers a rare opportunity to address the issue of $\mathrm{Pb}$ isotope behavior in volcanic fumaroles, as the composition of the degassing source is accurately and precisely known. Gas sublimates formed between 2007 and 2011 at temperature ranging from 400 to ca. $100{ }^{\circ} \mathrm{C}$ include $\mathrm{Na}-\mathrm{K}$ sulfate (aphthitalite), $\mathrm{Ca}-\mathrm{Cu}$ sulfate (e.g., gypsum), $\mathrm{Na}$ sulfate (thenardite), $\mathrm{Ca}-\mathrm{Mg}-\mathrm{Al}-\mathrm{Fe}$ fluoride (e.g., ralstonite) and native sulfur. The high-temperature deposits show trace element patterns typical of volcanic gas (with $\mathrm{Pb}$ concentration up to $836 \mathrm{ppm}$ ) while the lowtemperature deposits are depleted in most volatile elements $(\mathrm{Pb}<1 \mathrm{ppm})$ with the exception of $\mathrm{Pd}$ and $\mathrm{Tl}$ (in fluorides) and $\mathrm{Se}$ (in native sulfur).

Only for low-temperature fluoride samples do $\mathrm{Pb}$ isotope compositions plot significantly outside the field of lavas. The isotopic shift is ascribed to leaching ubiquitous unradiogenic phases (e.g., sulfides) by acidic gas condensates. The similarity in $\mathrm{Pb}$ isotope signature between lavas and sublimate samples more representative of the gas phase (sulfates) indicates that the net fractionation of $\mathrm{Pb}$ isotopes resulting from volatilization and condensation processes is smaller than the precision of $\mathrm{Pb}$ isotope measurements (better than 60 ppm/a.m.u.). The absence of net fractionation could result from negligible isotope fractionation during $\mathrm{Pb}$ volatilization followed by extensive condensation of gaseous $\mathrm{Pb}$, with possibly significant isotopic fractionation at this stage. Although this scenario has to be refined by more direct measurement of the gas phase, and its general applicability tested, it suggests that a small fraction $(<10 \%)$ of initially volatilized $\mathrm{Pb}$ ultimately escapes to the atmosphere, while the remaining dominant fraction is trapped in sublimates. As sublimates are rapidly dissolved and entrained by runoff, the fumarolic environment appears as a factory efficiently transferring isotopically unfractionated $\mathrm{Pb}$ from magmas towards the hydrological system and seawater.

Resolving very small isotopic differences between magmas and their gaseous products remains an analytical challenge. High-precision $\mathrm{Pb}$ isotope measurements rest not only on instrumental performance but also on high-yield chemistry, as $\mathrm{Pb}$ isotopes drastically fractionate $(800 \mathrm{ppm} / \mathrm{a} . \mathrm{m} . \mathrm{u}$.) upon elution on anionic resin. For $50 \% \mathrm{~Pb}$ recovery, the estimated isotopic bias is plus or minus 60-80 ppm/a.m.u., depending on which of the early (isotopically light) or late (isotopically heavy) $\mathrm{Pb}$ fraction is lost.
\end{abstract}

(C) 2012 Elsevier Ltd. All rights reserved.

\footnotetext{
* Corresponding author. Address: Laboratoire Magmas et Volcans, Observatoire de Physique du Globe de Clermont-Ferrand, UMR 6524, 5 Rue Kessler, 63038 Clermont-Ferrand, France. Tel.: +334733467 10; fax: +33473346744.

E-mail address: i.vlastelic@opgc.univ-bpclermont.fr (I. Vlastélic).
} 


\section{INTRODUCTION}

Amongst the four stable isotopes of lead, three $\left({ }^{208} \mathrm{~Pb}\right.$, $\left.{ }^{207} \mathrm{~Pb},{ }^{206} \mathrm{~Pb}\right)$ are produced at slow rate $\left(0.738<t^{1 /}\right.$ $2<14.01 \mathrm{Ga})$ by the decay of naturally occurring actinides $\left({ }^{232} \mathrm{Th},{ }^{235} \mathrm{U},{ }^{238} \mathrm{U}\right)$. This unique feature, together with the large fractionation of $\mathrm{U} / \mathrm{Pb}$ and $\mathrm{Th} / \mathrm{Pb}$ ratios occurring in nature, makes $\mathrm{Pb}$ a very useful geochemical tracer. Lead isotopes have been successfully used within a wide range of domains, including cosmochemistry, mantle geochemistry, environmental sciences, as well as archaeometry. Plumbology rests on the assumption that $\mathrm{Pb}$ stable isotopes do not fractionate by any processes other than radiogenic growth. Lead being volatile to some degree, the validity of this assumption has been early questioned in the case of sublimation or vaporization processes (e.g., Lindemann, 1915). Mass-dependent fractionation of $\mathrm{Pb}$ isotopes during experimental sublimation of $\mathrm{Pb}$ is now well established, in particular in the case of isotopic measurements by Thermal Ionization Mass Spectrometry (TIMS). Small but resolvable isotopic fractionation was also identified during heating experiments of $\mathrm{Pb}$ alloys (Budd et al., 1995; Cui and $\mathrm{Wu}, 2011)$. On the other hand, no volatilization-driven fractionation of $\mathrm{Pb}$ isotopes has been identified so far in nature (Houtermans et al., 1964; Ferrara et al., 1995; Vallelonga and Mather, 2003; Chugaev et al., 2007; Yudovskaya et al., 2008). In the absence of two stable, non-radiogenic $\mathrm{Pb}$ isotopes, any attempt to resolve such, necessarily small, fractionations is first hampered by the highly variable $\mathrm{Pb}$ isotope ratios in geological samples.

In this context, this contribution addresses the question of the extent to which $\mathrm{Pb}$ isotopes fractionate during volcanic degassing. This question is at the heart of a number of scientific issues that are relevant not only to volcanology but also to global geochemical cycles. (1) Magma sources have their own $\mathrm{Pb}$ isotopic signatures, which are clearly distinct from that of oceans (mostly continental derived lead) and atmosphere (mostly anthropogenic lead). If lead isotopes do not fractionate significantly during volatilization, then they may provide clues as to whether magmatic gases or their precursory fluids are contaminated by external components such as hydrothermal fluids, seawater brines and natural or anthropogenic aerosols. Such contaminations provide information on the permeability of volcanic edifices, which may change in response to seismic or tectonic events (Nonell et al., 2005). (2) Lead isotope time-series from active volcanoes show that the $\mathrm{Pb}$ isotope composition of magma sources changes at short-time scale (Pietruszka and Garcia, 1999; Marske et al., 2007; Vlastélic et al., 2009a). Providing that these temporal changes are large compared to those induced by $\mathrm{Pb}$ volatilization, the $\mathrm{Pb}$ isotope composition of volcanic emanations could be used to predict the arrival of new batches of magma at depth. (3) Highly precise isotopic measurements by MCICPMS recently showed that isotopes of intermediate $(\mathrm{Zn})$ and even heavy $(\mathrm{Tl})$ elements significantly fractionate during volcanic degassing (Toutain et al., 2008; Baker et al., 2009). Thus, it is possible that $\mathrm{Pb}$ isotopes fractionate to a measurable degree as well, then raising the question: what is the precise isotopic composition of the gas ultimately released to the atmosphere? This question is becoming more relevant as $\mathrm{Pb}$ isotope variations in the environment are measured with increasing precision (Kylander et al., 2010).

Unlike heavy stable isotopes, radiogenic $\mathrm{Pb}$ isotopes display large variations in the source of magmas. To study the behavior of $\mathrm{Pb}$ isotopes in fumaroles, one needs to know precisely the isotopic composition of $\mathrm{Pb}$ in the degassing magmatic source, which is not easy to determine, especially for quiescent degassing of subduction zone volcanoes. With respect to this problem, frequently active and continuously monitored basaltic volcanoes are more suitable, even if they often lack long-lived fumarole fields. Few studies have so far focused on trace element degassing at Piton de la Fournaise, the active volcano of Reunion island, because diffuse degassing of basaltic melts at depth hampers sampling of volcanic gases before their dilution in the atmosphere. Taking advantage of the recent intense activity of the volcano, we have sampled gas sublimates from short-lived fumaroles. The trace element content and the $\mathrm{Pb}$ isotope composition of the sublimate samples are compared to those of lavas, which have been previously extensively documented (see synthesis by Vlastélic et al., 2009a). Some differences are found, but for low-temperature deposits only, while the $\mathrm{Pb}$ isotope signature of high-temperature sublimates is indistinguishable from that of their magmatic source.

\section{GEOLOGICAL SETTING, GEOCHEMICAL BACKGROUND AND SAMPLES}

Piton de la Fournaise is a very active basaltic shield volcano with no less than 65 eruptions observed between 1972 and 2007 (see a review by Peltier et al., 2009). Most of the eruptions occurred within the main caldera and produced transitional basalts and episodically olivine-rich lavas. A wide range of observations, including earthquake locations, compositional variation and trapping pressure of olivine melt inclusions, eruption volumes and durations (e.g., Nercessian et al., 1996; Aki and Ferrazzini, 2001; Battaglia et al., 2005; Famin et al., 2009) are used to characterize the magma feeding system of this volcano. These data support the existence of a deep magma reservoir at the crust-mantle interface $(7.5 \mathrm{~km}$ below the summit) and a shallower reservoir near sea level $(2.5 \mathrm{~km}$ below the summit), while a network of sills and dykes makes the shallowest part of the plumbing system $(0.5-1 \mathrm{~km}$ below the surface). The lack of high-temperature springs on the flank of the volcano suggests little interaction between the hydrologic and the magmatic systems, perhaps because of the existence of an impervious shell around the shallow magma chamber (Violette et al., 1997). Hydrothermal activity seems to be confined to the summit crater, under which a low-resistivity zone was identified (Lénat et al., 2000). Lower hydrothermal activity has also been evidenced with self-potential technique along the North-South rift zone crossing the summit area (Barde-Cabusson et al., 2012). Piton de la Fournaise lacks persistent and localized degassing activity, so that sampling of magmatic gas is systematically hampered by atmospheric contamination. An analysis of the gases emitted during the December 1983 eruption revealed 
the main occurrence of $\mathrm{H}_{2} \mathrm{O}, \mathrm{CO}_{2}$ and $\mathrm{SO}_{2}$ with $\mathrm{S} / \mathrm{C}$ and $\mathrm{H} /$ $\mathrm{C}$ ratios of 1.06 and 12.5, respectively (Lénat et al., 1989). Similarly, little is known about natural gas sublimates ("sublimates" designate minerals formed directly from the gaseous phase, without the presence of an intermediate liquid), except the occurrence of thenardite $\left(\mathrm{Na}_{2} \mathrm{SO}_{4}\right)$ near the summit crater (Nativel, 1972). Our understanding of trace element degassing at Piton de la Fournaise rests on the works of Toutain and Meyer (1989) and Toutain et al. (1990) who collected sublimates in a silica tube emplaced in a crack during the August 1985 eruption. They identified mineral phases, namely halite $(\mathrm{NaCl})$, sylvite $(\mathrm{KCl})$ ), mitscherlichite $\left(\mathrm{K}_{2} \mathrm{CuCl}_{4} \cdot 2 \mathrm{H}_{2} \mathrm{O}\right)$ and hieratite $\left(\mathrm{K}_{2} \mathrm{SiF}_{6}\right)$, and pointed out (1) the increasing abundance of volatile trace elements $(\mathrm{Rb}, \mathrm{Cs}, \mathrm{Se}, \mathrm{Au}, \mathrm{Cu}, \mathrm{Pb}, \mathrm{Tl})$ in the condensing phases with decreasing temperature; (2) the absence of refractory elements ( $\mathrm{Sc}, \mathrm{Ta}, \mathrm{Hf}, \mathrm{Zr}$ ) as well as some volatile elements, such as transition metals $(\mathrm{Fe}, \mathrm{Co}, \mathrm{Zn})$ or chalcolphile elements (As, Sb); (3) the unique occurrence of iridium, this element being undetected in sublimates from other volcanoes (Toutain and Meyer, 1989).

In this study, incrustations were sampled at short-lived fumaroles, during or shortly after their activity. This sampling strategy is critical because most of the deposits are soluble into water. A first group of incrustations was sampled on and within the voluminous $\left(240 \mathrm{Mm}^{3}\right)$ and slowly cooling lava flow of April 2007 (Staudacher et al., 2009), especially in its thickest part (Fig. 1a). They include incrustations from an active vent (labeled "F" in Fig. 1a), whose temperature decreased from $\sim 400$ to $\sim 300{ }^{\circ} \mathrm{C}$ between $\mathrm{Au}-$ gust 2008 and November 2009, incrustations from nearby fumaroles that showed a vanishing activity $\left(\sim 100^{\circ} \mathrm{C}\right)$ in 2008 , and deposits formed in a lava cave. This cave is made of a lava tunnel network of $1700 \mathrm{~m}$ at an average depth of $20 \mathrm{~m}$ below the surface of the April 2007 flow. It was explored only in March 2011 when its temperature dropped as it vented. The highest temperature measured in this cave was $350{ }^{\circ} \mathrm{C}$, but the samples were collected at ambient temperature two months after venting. The second group of incrustations formed in near-summit cracks during the short (one day) eruptions of 5 November and 14 December 2009 (Fig. 1b). Sample characteristics are summarized in Table 1 and selected images are shown on Fig. 2.

\section{ANALYTICAL METHODS}

\subsection{Major element chemistry}

A selection of samples was investigated by scanning electron microscopy (SEM) (JSM 5910LV, Laboratoire Magmas et Volcans) in Backscattered Electron (BSE) imaging mode. Qualitative compositions in major and minor elements were also determined using Energy Dispersive Spectrometry (EDS). Representative samples were then selected, embedded in resin, pre-polished on $\mathrm{SiC}$ discs using ethanol, and polished using oil-based diamond suspensions in order to preserve water-soluble phases. The polished sections were analyzed for $\mathrm{O}, \mathrm{F}, \mathrm{Na}, \mathrm{Mg}, \mathrm{Al}, \mathrm{Si}, \mathrm{S}, \mathrm{Cl}, \mathrm{K}, \mathrm{Ca}, \mathrm{Ti}$, and $\mathrm{Fe}$ by Electron Probe Microanalysis (EPMA) on a Cameca SX 100 (Laboratoire Magmas et Volcans) operated at $15 \mathrm{kV}$. Low beam current (4 nA) and defocused beam $(10 \mu \mathrm{m})$ were used in order to minimize damage to the samples. To reduce the effect of water loss occurring during the course of an analysis, oxygen signal was measured first. Most phases being fine-grained (sub-micrometric) and beam sensitive, the results of analysis were validated only when all elements summed up between 95 and $105 \mathrm{wt} . \%$. Another set of samples was selected for powder X-ray Diffraction (XRD) obtained on a Bruker X'Pert Pro diffractometer.

\subsection{Sample dissolution and trace element analysis}

Incrustation samples turned out to be highly heterogeneous, at the scale of a single grain often made of fine concentric layers, but also at the microscopic scale because of the complex distribution of minerals (see Section 4). In order to preserve as much as possible the small-scale heterogeneity of the incrustations while recovering sufficient amount of elements for mass spectrometry analysis, between 4 and $150 \mathrm{mg}$ of sample were dissolved for wet chemistry. Sulfate samples (4-50 mg) were fully and rapidly dissolved at room temperature in $4 \mathrm{ml}$ of $7 \mathrm{M} \mathrm{HNO}_{3}$. Fluorides samples $(150 \mathrm{mg})$ were digested in $4 \mathrm{ml}$ of $1.5 \mathrm{M}$ $\mathrm{HNO}_{3}$ saturated in $\mathrm{H}_{3} \mathrm{BO}_{3}$. Total dissolution was achieved only after several days, alternating heat $\left(90^{\circ} \mathrm{C}\right)$ and ultrasonic treatments. Nitric acid was replaced by hydrochloric acid when osmium analyses were planned on the same dissolutions. Hydrofluoric acid was used to eliminate excess of boron as gaseous $\mathrm{BF}_{3}$. Native sulfur deposits $(50 \mathrm{mg})$ were dissolved with $3 \mathrm{ml}$ of concentrated $\mathrm{HNO}_{3}$ in PARR 4749 bombs, which were heated at $150{ }^{\circ} \mathrm{C}$ for $24 \mathrm{~h}$ (Lechler and Desilets, 1990). Oxidation of native sulfur yields sulfuric acid, which was not evaporated (boiling point of ca. $290{ }^{\circ} \mathrm{C}$ ) but further diluted in $7 \mathrm{M} \mathrm{HNO}_{3}$.

Trace element abundances were determined by ICP-MS (Agilent 7500, Laboratoire Magmas et Volcans). Dissolved samples were evaporated to near dryness and subsequently diluted in $0.4 \mathrm{M} \mathrm{HNO}_{3}$ to reach a total dilution factor ranging from 3000 to 15,000 , depending on the degree of trace element enrichment. The analyses were performed in plasma robust mode $(1550 \mathrm{~W})$. The reaction cell $(\mathrm{He}$ mode) was used to reduce interferences on masses ranging from $45(\mathrm{Sc})$ to 77 (Se). The signal was calibrated externally with a synthetic standard. Both standards and pure $0.4 \mathrm{M} \mathrm{HNO}_{3}$ were measured every four samples. Mass interferences of oxides and doubly charged ions were monitored externally by running successively multi-element standards. The external two-sigma reproducibility of the method, as estimated by repeatedly running rock standards (such as BHVO-2) is $<5 \%$ for most lithophile elements and $<15 \%$ for most chalcophile and siderophile elements. Reproducibility was not tested on sublimate powders because of the heterogeneity and relatively small size of the samples. Although the concentration of platinum group elements and gold are usually not determined by this method, they are reported for some sulfate samples which (1) are soluble in $\mathrm{HCl}$, (2) contain very low amounts of $\mathrm{Hf}$ and $\mathrm{Ta}$ (whose oxides generate spectral interferences on $\mathrm{Ir}, \mathrm{Pt}$ and $\mathrm{Au}$ ), (3) have concentrations of these elements in the range of $\mathrm{ppb}$ to $\mathrm{ppm}$. 


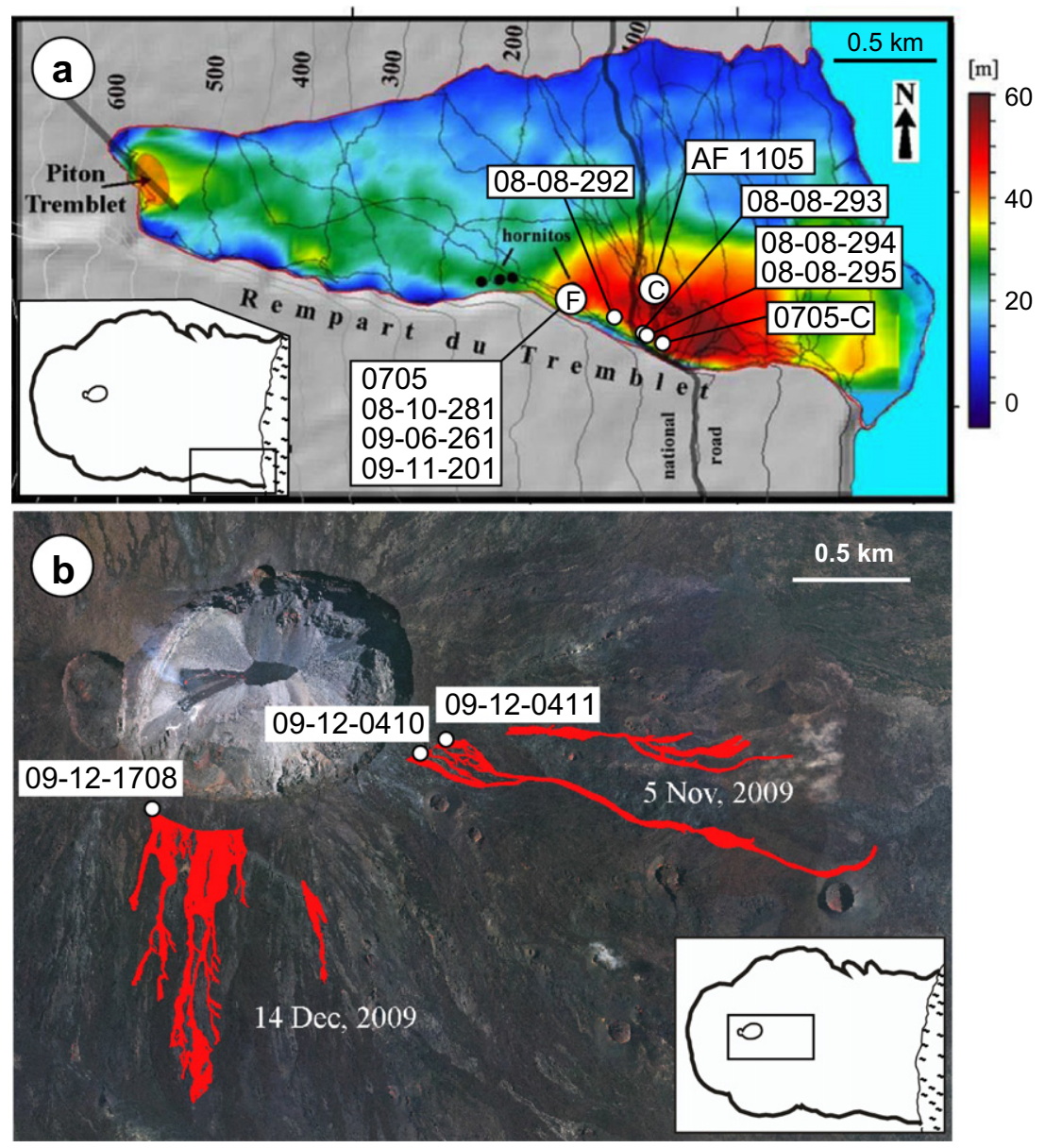

Fig. 1. Location of the fumarolic incrustations analyzed in this study. (a) Map of the April 2007 lava flow with color coded thickness (from Staudacher et al., 2009). F: $400-300{ }^{\circ} \mathrm{C}$ fumarolic vent repeatedly sampled in 2008 and 2009. C: lava cave explored in 2011 (a lava tunnel network of $1700 \mathrm{~m}$ at an average depth of $20 \mathrm{~m}$ below the surface of the April 2007 flow). (b) Map of the summit area of Piton de la Fournaise showing the locations of the eruptions of November 5 and December 14, 2009. Insets show eruption locations within the U-shaped caldera. (For interpretation of the references to color in this figure legend, the reader is referred to the web version of this article.)

\section{3. $\mathrm{Pb}$ purification and $\mathrm{Pb}$ isotope analysis}

Dissolved samples were evaporated to dryness and lead was converted to bromide form with a few drops of concentrated $\mathrm{HBr}$. Lead was purified on $100 \mu \mathrm{l}$ Teflon columns filled with strong anion exchange resin (Bio-Rad AG1-X8 100-200 mesh with a capacity of $1.2 \mathrm{meq} / \mathrm{ml}$ ) using different mixtures of $\mathrm{HNO}_{3}$ and $\mathrm{HBr}$ (Strelow, 1978; Lugmair and Galer, 1992). Samples were systematically passed twice through columns. Optimal retention of $\mathrm{Pb}$ while most chalcophile elements $(\mathrm{Cu}, \mathrm{Zn}, \mathrm{Sn}, \mathrm{In})$ are eluted occurs with $0.2 \mathrm{M} \mathrm{HBr}-0.5 \mathrm{M} \mathrm{HNO}_{3}$ (solution A). Lead is selectively eluted with $0.03 \mathrm{M} \mathrm{HBr}-0.5 \mathrm{M} \mathrm{HNO}_{3}$ (solution $\mathrm{B}$ ), while $\mathrm{Cd}$ and $\mathrm{Bi}$ are retained on the column (Fig. 3a). As previously shown (Blichert-Toft et al., 2003; Baker et al., 2004), permil level fractionation of $\mathrm{Pb}$ isotopes occurs during elution on anionic resin (Fig. 3b), so it is essential to recover $100 \%$ of $\mathrm{Pb}$, especially when tracking small isotope variations. The elution scheme was thus determined precisely using the two types of samples analyzed in this study (sulfate and fluoride) (Fig. 3a and c), and the absence of measurable isotopic fractionation $(<100 \mathrm{ppm})$ was checked processing the NBS981 standard through column. Although the column capacity $(0.12 \mathrm{meq})$ is theoretically sufficient to separate large amounts of lead $(100 \mu \mathrm{g}$ of $\mathrm{Pb}$ occupying less than $1 \%$ of the column capacity), the $\mathrm{Pb}$ elution peak significantly enlarges as the amount of loaded $\mathrm{Pb}$ increases. This effect becomes critical when the amount of $\mathrm{Pb}$ loaded exceeds $15 \mu \mathrm{g}$. The highest $\mathrm{Pb}$ yields were obtained when loading no more than $6 \mu \mathrm{g}$ of $\mathrm{Pb}$ (corresponding to less than $10 \mathrm{mg}$ of the $\mathrm{Pb}$-rich sulfates). Note also that chemistry yields of only $30-50 \%$ were initially obtained for $\mathrm{Pb}$-depleted fluorides dissolved using boric acid. In this latter case, we observed that a major fraction of $\mathrm{Pb}$ (ca. $50 \%$ ) is not retained on column during sample loading. This early $\mathrm{Pb}$ loss coincides with elution of significant amounts of boron, which was not totally eliminated despite repeated $\mathrm{HF}$ addition-evaporation steps. We concluded that the early $\mathrm{Pb}$ loss results from a competition between $\mathrm{PbBr}_{3}{ }^{-}$ and $\mathrm{BF}_{4}{ }^{-}$, the tetrafluoroborate anion having high affinity for the anionic resin (Nakamura et al., 1992). An optimized method avoiding the use of boric acid was set up to extract 
Table

Characteristics of the fumarolic incrustations.

\begin{tabular}{|c|c|c|c|c|c|c|c|}
\hline Sample name & Lat. (S) & Long. (E) & Date & Temperature* & Description & Dominant mineralogy & Comments \\
\hline REU 0705 & $21^{\circ} 17^{\prime} 14.8^{\prime \prime}$ & $55^{\circ} 47^{\prime} 34^{\prime \prime}$ & $2008 / 06$ & $400{ }^{\circ} \mathrm{C}$ & $\begin{array}{l}\text { Greenish cm-thick } \\
\text { vesicular agglomerate }\end{array}$ & Aphthitalite $(\mathrm{K}, \mathrm{Na})_{3} \mathrm{Na}\left(\mathrm{SO}_{4}\right)_{2}$ & April 2007 eruption \\
\hline REU 0810-281 & $21^{\circ} 17^{\prime} 14.8^{\prime \prime}$ & $55^{\circ} 47^{\prime} 34^{\prime \prime}$ & $2008 / 10$ & $384^{\circ} \mathrm{C}$ & $\begin{array}{l}\text { Pale yellow to greenish } \\
\text { agglomerate }\end{array}$ & Thenardite $\mathrm{Na}_{2} \mathrm{SO}_{4}$ & $\begin{array}{l}\text { thickest part of the lava flow post- } \\
\text { eruptive degassing }\end{array}$ \\
\hline REU 0906-261 & $21^{\circ} 17^{\prime} 14.8^{\prime \prime}$ & $55^{\circ} 47^{\prime} 34^{\prime \prime}$ & 2009/06 & $345^{\circ} \mathrm{C}$ & “ & & \\
\hline REU 0911-201 & $21^{\circ} 17^{\prime} 14.8^{\prime \prime}$ & $55^{\circ} 47^{\prime} 34^{\prime \prime}$ & $2009 / 11$ & $325^{\circ} \mathrm{C}$ & “ & & \\
\hline AF $1105 \mathrm{G}$ & $21^{\circ} 17^{\prime} 17.1^{\prime \prime}$ & $55^{\circ} 47^{\prime} 46.2^{\prime \prime}$ & $2011 / 05$ & cold & $\begin{array}{l}\text { Bluegreen, well-formed } \\
\text { mm-sized crystals }\end{array}$ & $\begin{array}{l}\text { Gypsum } \mathrm{Ca}\left(\mathrm{SO}_{4}\right) \cdot 2 \mathrm{H}_{2} \mathrm{O} \text { and } \\
\text { unidentified } \mathrm{Cu} \text { sulfate }\end{array}$ & roof of lava tunnel \\
\hline AF $1105 \mathrm{~W}$ & $21^{\circ} 17^{\prime} 17.1^{\prime \prime}$ & $55^{\circ} 47^{\prime} 46.2^{\prime \prime}$ & $2011 / 05$ & cold & $\begin{array}{l}\text { White, well-formed mm- } \\
\text { sized crystals }\end{array}$ & & \\
\hline REU 0808-292 & $21^{\circ} 17^{\prime} 17.5^{\prime \prime}$ & $55^{\circ} 47^{\prime} 41.2^{\prime \prime}$ & $2008 / 08$ & $100^{\circ} \mathrm{C}$ & $\begin{array}{l}\text { Thin crystalline white } \\
\text { deposits }\end{array}$ & Thenardite $\mathrm{Na}_{2} \mathrm{SO}_{4}$ & \\
\hline REU 0808-293 & $21^{\circ} 17^{\prime} 19.7^{\prime \prime}$ & $55^{\circ} 47^{\prime} 45.8^{\prime \prime}$ & $2008 / 08$ & $100^{\circ} \mathrm{C}$ & $\begin{array}{l}\text { Thin shells on lava, red- } \\
\text { yellow-brown }\end{array}$ & $\begin{array}{l}\text { Na-poor Ralstonite } \\
\left(\mathrm{Na}_{X} \mathrm{Mg}_{\mathrm{X}} \mathrm{Al}_{2-\mathrm{X}}(\mathrm{F}, \mathrm{OH})_{6} \cdot \mathrm{H}_{2} \mathrm{O}\right)\end{array}$ & \\
\hline REU 0808-294 & $21^{\circ} 17^{\prime} 19.8^{\prime \prime}$ & $55^{\circ} 47^{\prime} 46.1^{\prime \prime}$ & $2008 / 08$ & $100^{\circ} \mathrm{C}$ & “ & $\begin{array}{l}\text { Leonardsenite } \\
\left(\mathrm{MgAlF}_{5} \cdot 2 \cdot 0 \mathrm{H}_{2} \mathrm{O}\right)\end{array}$ & \\
\hline REU 0808-295-Y & $21^{\circ} 17^{\prime} 19.8^{\prime \prime}$ & $55^{\circ} 47^{\prime} 46.1^{\prime \prime}$ & $2008 / 08$ & $100{ }^{\circ} \mathrm{C}$ & $\begin{array}{l}\text { Bright yellow 3-4 mm } \\
\text { globules }\end{array}$ & $\begin{array}{l}\text { unidentified } \mathrm{Ca}-\mathrm{Mg}-\mathrm{Al}-\mathrm{Fe} \\
\text { fluoride hydroxide }\end{array}$ & \\
\hline REU 0808-295-W & $21^{\circ} 17^{\prime} 19.8^{\prime \prime}$ & $55^{\circ} 47^{\prime} 46.1^{\prime \prime}$ & $2008 / 08$ & $100^{\circ} \mathrm{C}$ & $\begin{array}{l}\text { White } 1-4 \mathrm{~mm} \text { dentritic } \\
\text { stalagmite }\end{array}$ & & \\
\hline REU 0705-C & $21^{\circ} 17^{\prime} 21.9^{\prime \prime}$ & $55^{\circ} 47^{\prime} 50.4^{\prime \prime}$ & $2008 / 06$ & $100^{\circ} \mathrm{C}$ & Thin white crusts & & \\
\hline REU 091204-11 & $21^{\circ} 14^{\prime} 45.3^{\prime \prime}$ & $55^{\circ} 43^{\prime} 15.6^{\prime \prime}$ & $2009 / 12$ & cold & Bright white powder & Thenardite $\mathrm{Na}_{2} \mathrm{SO}_{4}$ & $\begin{array}{l}\text { November } 2009 \text { eruption } \\
\text { Crack linking two active vents } \\
\text { syn-eruptive degassing }\end{array}$ \\
\hline REU 091204-10 & $21^{\circ} 14^{\prime} 47.8^{\prime \prime}$ & $55^{\circ} 43^{\prime} 12.4^{\prime \prime}$ & 2009/12 & cold & Bright yellow & Native sulfur & \\
\hline REU 091217-08 & $21^{\circ} 14^{\prime} 53.59^{\prime \prime}$ & $55^{\circ} 42^{\prime} 35.5^{\prime \prime}$ & $\begin{array}{l}2009 / 12 / \\
14 \\
\text { to } 2010 / \\
01 / 05\end{array}$ & $<100^{\circ} \mathrm{C}$ & Bright yellow & Native sulfur & $\begin{array}{l}\text { December } 2009 \text { eruption silica } \\
\text { tube emplaced in a crack }\end{array}$ \\
\hline
\end{tabular}



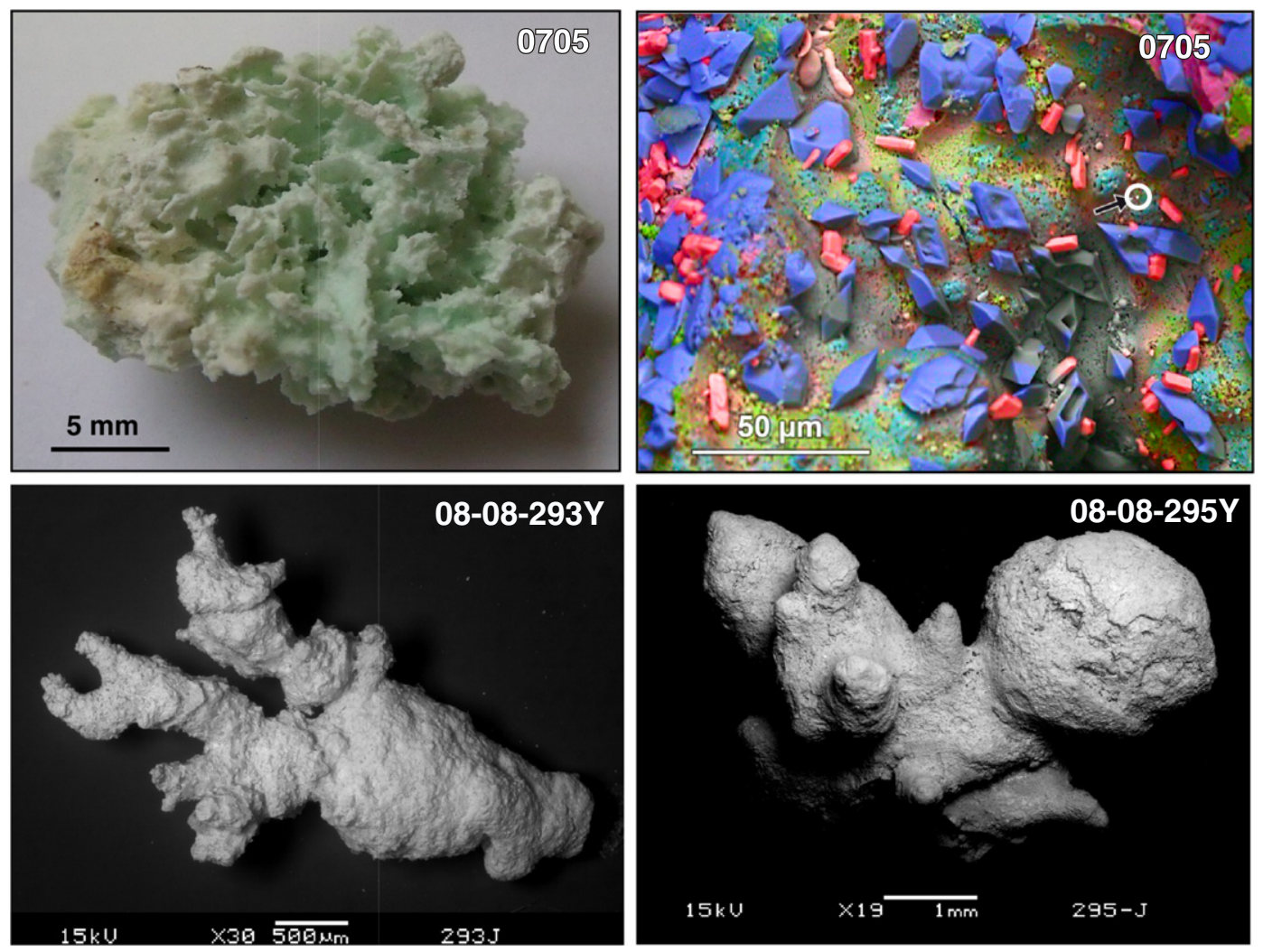

Fig. 2. Macroscopic photos and SEM images of the gas sublimates. Upper left panel: photo of the Na-K sulfate (REU 0705). Upper right panel: SEM image of REU 0705 with major element mapping. Color code: Red: K; Blue: Na; Green: Mg. The occurrence of a gold nugget is highlighted. Lower panels: SEM images of selected fluoride samples. X-ray diffraction analysis identified ralstonite and $\mathrm{MgAlF}_{5} \cdot 1.5 \mathrm{H}_{2} \mathrm{O}$ within these samples. (For interpretation of the references to color in this figure legend, the reader is referred to the web version of this article.)

quantitatively $\mathrm{Pb}$ from fluoride samples without significant loss (Fig. 3c). Samples were crushed in an agate mortar and partially dissolved in $7 \mathrm{M} \mathrm{HNO}_{3}$. Fluorine was eliminated as gaseous HF by repeatedly adding and evaporating small volumes $(300 \mu \mathrm{l})$ of concentrated $\mathrm{HNO}_{3}$. Lead was subsequently quantitatively recovered by leaching twice the precipitate with solution A in an ultrasonic bath.

Organic material and $\mathrm{Br}$ left after chemical separation were eliminated with a few drops of concentrated $\mathrm{HNO}_{3}$. The amount of $\mathrm{Pb}$ recovered from columns, and thus from the full process of extraction and purification was measured at this stage by analyzing an aliquot of the solutions by quadrupole ICP-MS. This amount was then compared to that expected from the weight and $\mathrm{Pb}$ concentration of the dissolved samples in order to estimate yields. Samples were not further processed when $\mathrm{Pb}$ recovery was lower than $95 \%$. After optimal dilution (40-60 ppb Pb solutions), isotopic compositions were measured automatically by MC-ICPMS (Nu Plasma HR and Nu Plasma 1700 instruments of the Ecole Normale Supérieure de Lyon) using a Tl spike (NBS 997) to monitor internally instrumental mass fractionation (White et al., 2000). Samples were introduced through a desolvator $(\mathrm{Nu}$ DSN) at a rate of $100 \mu \mathrm{l} / \mathrm{min}$, yielding a total $\mathrm{Pb}$ beam of ca. $6 \cdot 10^{-11} \mathrm{~A}$ for $40 \mathrm{ppb} \mathrm{Pb}$ solutions. Each analysis lasted $10 \mathrm{~min}(120 \mathrm{~s}$ uptake followed by 40 measurement cycles) and typically consumed between 40 and $60 \mathrm{ng}$ of $\mathrm{Pb}$. The NBS 981 standard was measured every two samples, and each sample analysis was normalized to the average value of the two bracketing standards. Normalization to bracketing standards corrects for both shifts between analysis sessions (five sessions between 2008 and 2012) and drifts within individual sessions (typically $24 \mathrm{~h}$ ). Statistical analysis (standard-standard bracketing) of standard data yields a precision $(2 \sigma$ error) of 129,155 and $178 \mathrm{ppm}$ for ${ }^{206} \mathrm{~Pb} /{ }^{204} \mathrm{~Pb},{ }^{207} \mathrm{~Pb} /{ }^{204} \mathrm{~Pb}$ and ${ }^{208} \mathrm{~Pb} /{ }^{204} \mathrm{~Pb}$ ratios, respectively. As shown in the result section, a precision better than $100 \mathrm{ppm}$ for all three ratios is attainable when averaging individual analyses. To be directly comparable with previously published data on lavas (Vlastélic et al., 2009a), the data already corrected for mass bias and instrumental drift were renormalized to the NBS981 values of Todt et al. (1996). Total $\mathrm{Pb}$ procedural blanks $\left(\mathrm{HNO}_{3}\right.$ dissolution) were measured using the ${ }^{206} \mathrm{~Pb}$-enriched NBS983 spike and range between 7 and 13 pg $(n=3)$. These blanks are negligible compared to the amount of lead purified ( $>35 \mathrm{ng}$ ). Nevertheless, the $\mathrm{Pb}$ isotope composition of the air of the clean room was measured by leaving a beaker open for one month, adding $10 \mathrm{~mL}$ of ultrapure water (plus a few $\mathrm{mL}$ every week to compensate for evaporation) to trap and dissolve aerosols. The final solution containing about $5 \mathrm{ng} \mathrm{Pb}$ was passed once through the anion exchange resin before measuring its isotope 


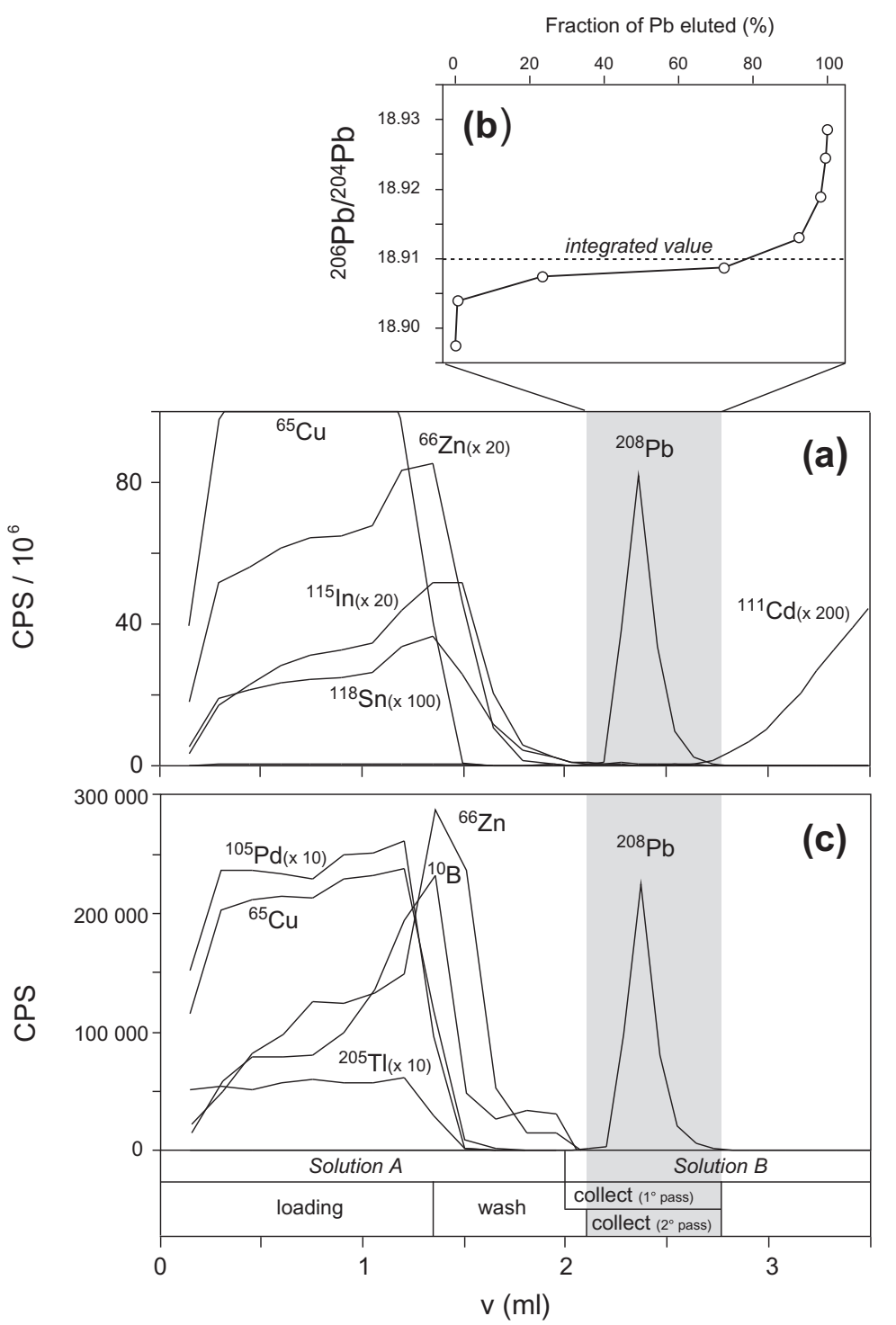

Fig. 3. Elution of lead on AG1-X8 resin (100-200 mesh) using $\mathrm{HNO}_{3}-\mathrm{HBr}$ mixtures. The column (made of Teflon shrink tubing) has a volume of $100 \mu \mathrm{l}(2 \mathrm{~mm}$ I.D. $\times 30 \mathrm{~mm})$. Curves were obtained by dissolving and loading samples of gas sublimate. (a, b) Dissolution of $50 \mathrm{mg}$ of $\mathrm{Na}-\mathrm{K}$ sulfate (sample 0911-201) with ca. $280 \mathrm{ppm}$ of $\mathrm{Pb}$. (b) Pb isotope fractionation across the elution peak (800 ppm/a.m.u.). (c) Dissolution of $150 \mathrm{mg}$ of fluorides (sample $0808-295 \mathrm{Y}$ ) with ca. $0.3 \mathrm{ppm}$ of Pb. Solution A: $0.2 \mathrm{M} \mathrm{HBr}-0.5 \mathrm{M} \mathrm{HNO}_{3}$. Solution B: $0.03 \mathrm{M}$ $\mathrm{HBr}-0.5 \mathrm{M} \mathrm{HNO}_{3}$. CPS: ICP-MS counts per second on the specified masses. (a,c) Note that the position and shape of the Pb peak do not depend on sample matrix or $\mathrm{Pb}$ concentration.

composition $\quad\left({ }^{206} \mathrm{~Pb} /{ }^{204} \mathrm{~Pb}=17.440 \pm 0.007, \quad{ }^{207} \mathrm{~Pb} /{ }^{204-}\right.$ $\mathrm{Pb}=15.553 \pm 0.006$ and $\left.{ }^{208} \mathrm{~Pb} /{ }^{204} \mathrm{~Pb}=37.386 \pm 0.015\right)$.

A subset of the sublimate samples was also analyzed for $\mathrm{Li}, \mathrm{Sr}$ and $\mathrm{Nd}$ isotopic compositions following the methods described in Vlastélic et al. (2009a,b).

\section{RESULTS}

\subsection{Sample mineralogy}

Major element concentrations from EPMA are reported in Supplementary Table A and plotted on Fig. 4. The incrustations that formed between 300 and $400{ }^{\circ} \mathrm{C}$ during degassing of the April 2007 lava flow are $\mathrm{Na}-\mathrm{K}$ sulfates with minor amounts of $\mathrm{Mg}$ (Fig. 4a). Chemical mapping of sample REU 0705 shows that $\mathrm{K}$ and $\mathrm{Na}$ are heterogeneously distributed at the microscopic scale (Fig. 2), with euhedral crystals of aphthitalite $\left((\mathrm{K}, \mathrm{Na})_{3} \mathrm{Na}\left(\mathrm{SO}_{4}\right)_{2}\right)$ and thenardite $\left(\mathrm{Na}_{2} \mathrm{SO}_{4}\right)$ lying on (and in) a fine-grained matrix of $\mathrm{K}-\mathrm{Na}-\mathrm{Mg}$ sulfates. EPMA analyses of the fine-grained matrix (Fig. 4a) are consistent with a mixture of aphthitalite and thenardite. XRD spectrum also suggests the occurrence of langbeinite $\left(\mathrm{K}_{2} \mathrm{Mg}_{2}\left(\mathrm{SO}_{4}\right)_{3}\right)$. The samples AF $1105 \mathrm{G}$ and AF $1105 \mathrm{~W}$ collected in the lava cave that formed within the April 2007 lava flow are gypsum $\left(\mathrm{Ca}\left(\mathrm{SO}_{4}\right) \cdot 2 \mathrm{H}_{2} \mathrm{O}\right)$ with minor amount of $\mathrm{Cu}$ sulfate (not yet identified), while the lowtemperature incrustations deposited at the surface of the lava flow contain either a suite of $\mathrm{Ca}-\mathrm{Mg}-\mathrm{Al}-(\mathrm{Fe})$ 
(a)

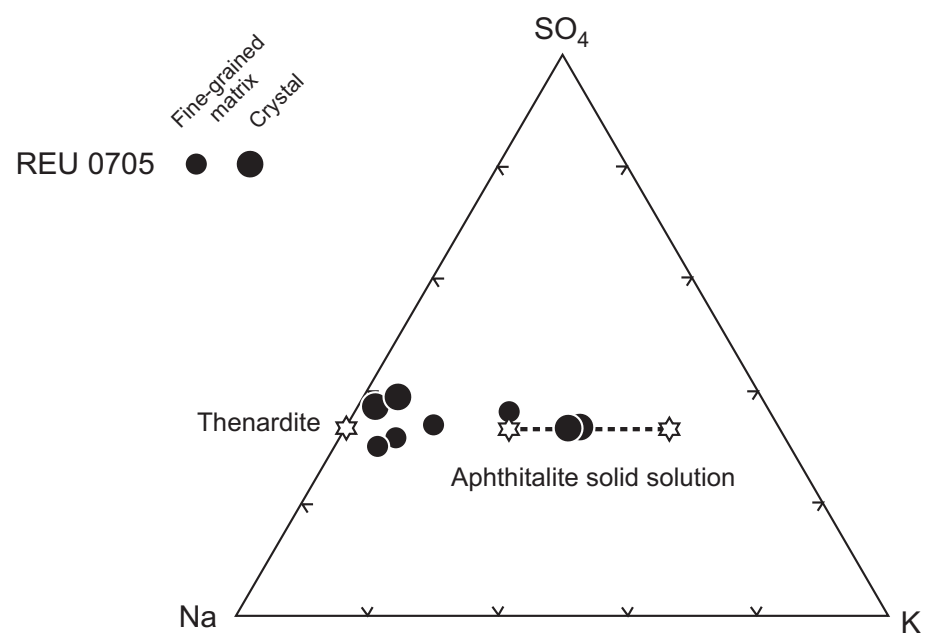

(b)

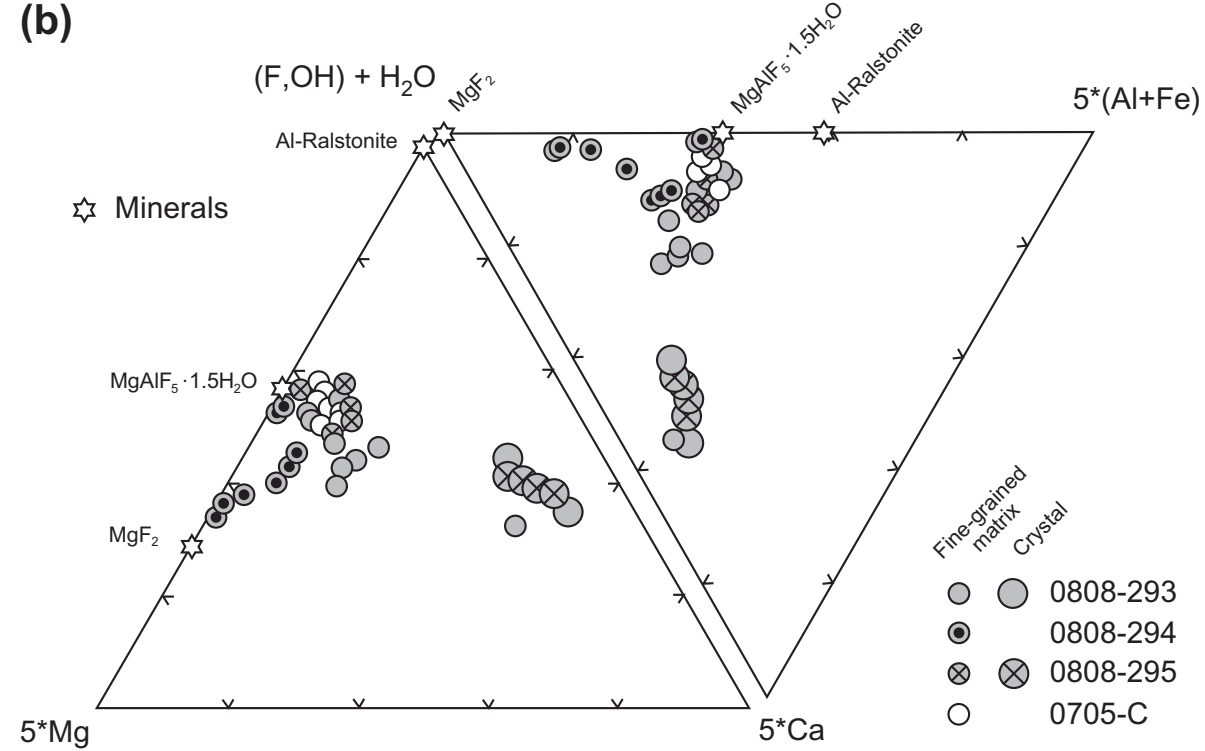

Fig. 4. Major element chemistry of sulfate and fluoride deposits (Electron microprobe data from Supplementary Table A). (a) Compositional variation within the REU 0705 sulfate sample. (b) Compositional variation of fluoride samples. Compositions are reported as relative atomic abundances. The compositions of selected reference minerals are also plotted (stars).

hydroxy-fluorides (0808-293, 0808-294, 0808-295, 0705C) or thenardite (0808-292). Electron microprobe analysis of fluorides revealed a wide range of compositions $(0.6<\mathrm{Ca}<32$ wt. $\%, 3.7<\mathrm{Mg}<32.1$ wt. $\%, 0<\mathrm{Al}<14.9$ wt. $\%$, $0<\mathrm{Fe}<16 \mathrm{wt} . \%$ ), and the occurrence of Ca-rich euhedral crystals in (or on) a fine-grained matrix of dominantly Al-Mg fluorides (Fig. 4b). According to XRD spectra, the main crystalline phases are ralstonite $\left(\mathrm{Na}_{X} \mathrm{Mg}_{X} \mathrm{Al}_{2-\mathrm{X}}\right.$ $\left.(\mathrm{F}, \mathrm{OH}) 6 \cdot \mathrm{H}_{2} \mathrm{O}\right)$ and $\mathrm{MgAlF}_{5} \cdot 1 \cdot 5 \mathrm{H}_{2} \mathrm{O}$. There is no clear compositional trend amongst the four fluoride samples. The chemical variability can be interpreted as a mixing between three components. From EPMA analyses and XRD, the first end-member is clearly $\mathrm{MgAlF}_{5} \cdot 1 \cdot 5 \mathrm{H}_{2} \mathrm{O}$, known as a synthetic phase and recently described in fumarolic minerals from Iceland (Jakobsson et al., 2008; Mitolo et al., 2010). The second pole is defined by the euhedral crystals, with compositions clustering around a mean $\mathrm{Na}_{0.08}$
$\begin{array}{llllll}\mathrm{Mg}_{0.47} & \mathrm{Al}_{0.32} & \mathrm{Ca}_{1.66} & \mathrm{Fe}_{0.17} & \mathrm{~F}_{6} & \left(\mathrm{H}_{2} \mathrm{O}\right)_{0.94} \\ \text { composition }\end{array}$ (assuming all oxygen is from $\mathrm{H}_{2} \mathrm{O}$ ). The third pole has a composition close to $\mathrm{MgF}_{2}$.

The samples from the November and December 2009 cracks were qualitatively analyzed by EDS. The white powder (091204-11) is thenardite, while the nearby bright yellow deposits (091204-10 and 091217-08) are native sulfur.

\subsection{Trace elements}

Trace element concentrations (together with $\mathrm{Li}, \mathrm{Sr}$ and $\mathrm{Nd}$ isotope data) are reported in Supplementary Table B. Enrichment factors (EF) are shown on Fig. 5 using beryllium as the normalizing element (Moune et al., 2006) and the most common type of lava (steady-state basalts) as the reference magmatic source. The $\mathrm{Na}-\mathrm{K}$ sulfates show trace element patterns typical of volcanic gas (Toutain 
(a)

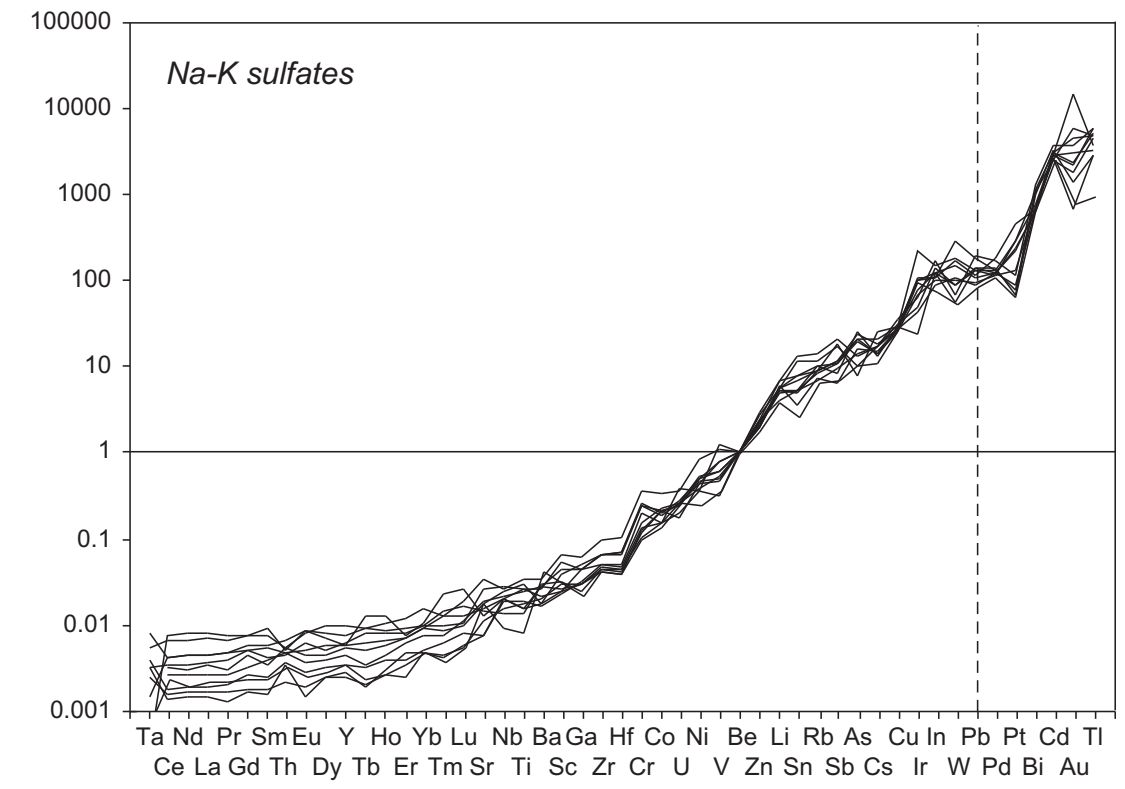

(b)

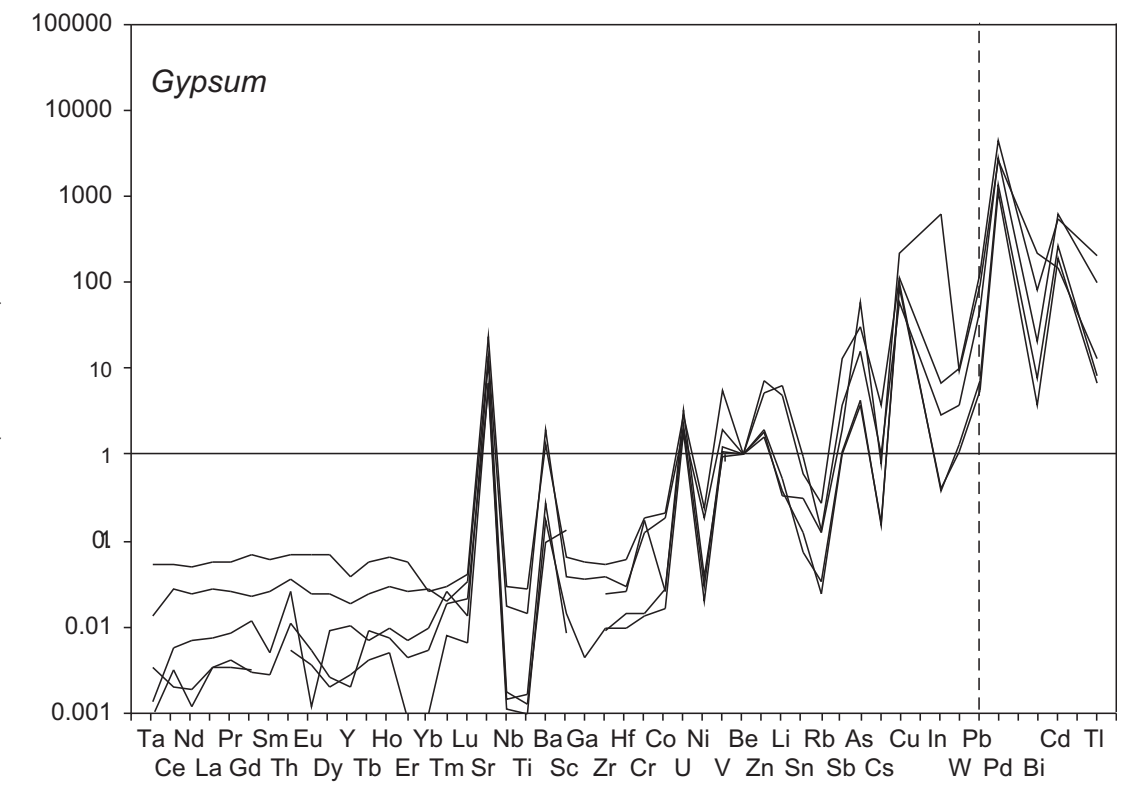

Fig. 5. Enrichment factors of trace elements in K-Na sulfate (a), gypsum (b), thenardite (c) and fluoride (d) deposits. Enrichment factor (EF) is defined as $\mathrm{EF}_{X}=\left(X / X_{R}\right)_{\text {sublimate }} /\left(X / X_{R}\right)_{\text {lava, }}$, where $X$ is the element of interest and $X_{R}$ the refractory element of reference. Beryllium was chosen because of its low volatility and low abundance in lavas (Moune et al., 2006). Normalization is made to the average composition of steady-state basalts (given in Supplementary Table B). Elements are sorted according to their mean enrichment factor in K-Na sulfates.

et al., 1990; Rubin, 1997) with depletion $\left(\mathrm{EF}_{\mathrm{Be}}<1\right)$ in rare earth elements and high field strength elements and enrichment $\left(\mathrm{EF}_{\mathrm{Be}}>1\right)$ in alkalis, platinum group elements, gold, and chalcophile elements (Fig. 5a). Over the small temperature range $\left(400-325^{\circ} \mathrm{C}\right)$, the enrichment factors of most volatile elements, with the exception of the platinum group elements and gold, tend to decrease with increasing temperature (not shown). The identification of micrometric Au nuggets in SEM images (Fig. 2) suggests that the large concentration range observed for $\mathrm{Au}$, but also $\mathrm{Ir}$ and $\mathrm{Pt}$, reflects their heterogeneous distribution in the incrustation samples. Trace element distributions in other incrustation types are reported sorting elements according to their enrichment in the high-temperature samples. The gypsum samples (Fig. 5b) also show gas-type patterns, although the depletion in refractory elements and the enrichment in volatile elements are not as pronounced as in the $\mathrm{Na}-\mathrm{K}$ sulfates, especially for $\mathrm{Sr}$ and $\mathrm{Ba}$ (anomalously enriched) and $\mathrm{Rb}$, Cs (anomalously depleted). The thenardite powder (091204-11) shows a volatile-element enriched pattern (Fig. 5c), but the left side of the pattern (i.e. from Ta to $\mathrm{Lu})$ is roughly flat indicating that non-volatile elements are not as depleted as expected in the gas phase. This is true for rare earth elements and also for $\mathrm{Sr}$, this latter being 

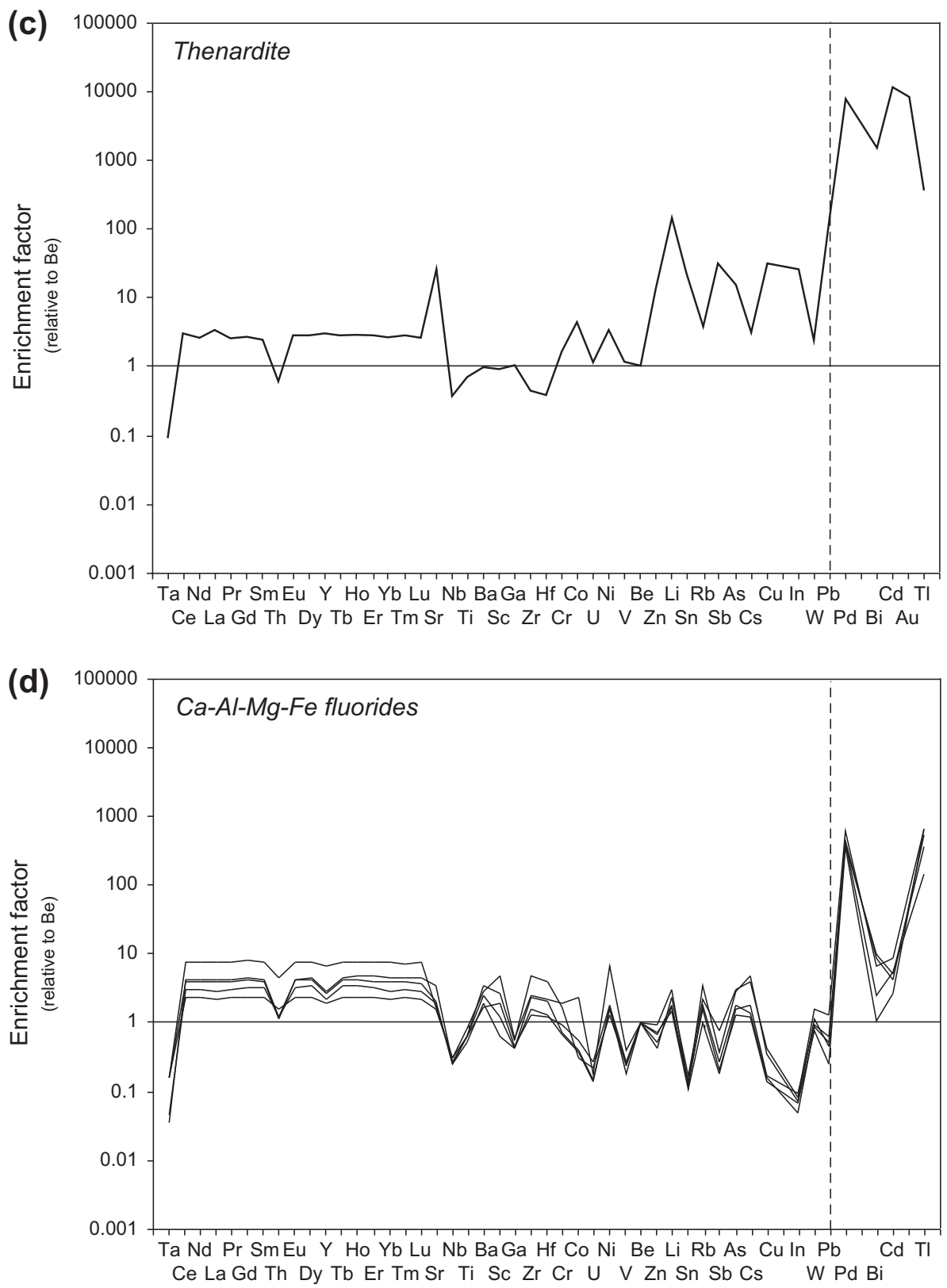

Fig. 5. (continued)

enriched as moderately volatile elements. The second thenardite sample occurring as thin crusts (0808-292) shows a similar pattern (not plotted) although shifted towards lower concentrations. Given the high dissolution rate of thenardite into water, it is possible that this sample was already altered at the time it was collected. Fluoride samples show rather flat patterns (Fig. $5 \mathrm{~d}$ ), $\mathrm{EF}_{\mathrm{Be}}$ being between 0.1 and 10 for most elements with the exception of $\mathrm{Pd}$ and $\mathrm{Tl}$, which are more enriched $\left(200<\mathrm{EF}_{\mathrm{Be}}<800\right)$. Native sulfur deposits (not plotted) are extremely depleted in most analyzed trace elements (a few ppb at the most). Striking exceptions are $\mathrm{Zn}$ and, particularly, Se whose concentration reaches hundreds of ppm, as previously observed in sulfur deposits from Poas volcano (Toutain, 1987).

\section{3. $\mathrm{Pb}$ isotopes}

Lead isotopic compositions of the gas sublimates are reported in Table 2. In $\mathrm{Pb}-\mathrm{Pb}$ isotope space (Fig. 6), the $\mathrm{Pb}$ isotope compositions of fluorides plot significantly outside the field of lavas. Most fluoride samples (0808-293, 0808294 and 0808-295) plot between the main field of 2007 2009 lavas and the anomalous unradiogenic composition measured in one lava sample erupted on April 6, 2007. Sample 0705C stands out from other fluoride samples, with less radiogenic ${ }^{206} \mathrm{~Pb} /{ }^{204} \mathrm{~Pb}$ and ${ }^{208} \mathrm{~Pb} /{ }^{204} \mathrm{~Pb}$ ratios, but more radiogenic ${ }^{207} \mathrm{~Pb} /{ }^{204} \mathrm{~Pb}$ than lavas.

All sulfate samples, including gypsum, thenardite and $\mathrm{K}-\mathrm{Na}$ sulfate, plot within error within the main isotope 
Table 2

$\mathrm{Pb}$ isotope compositions of fumarole incrustations.

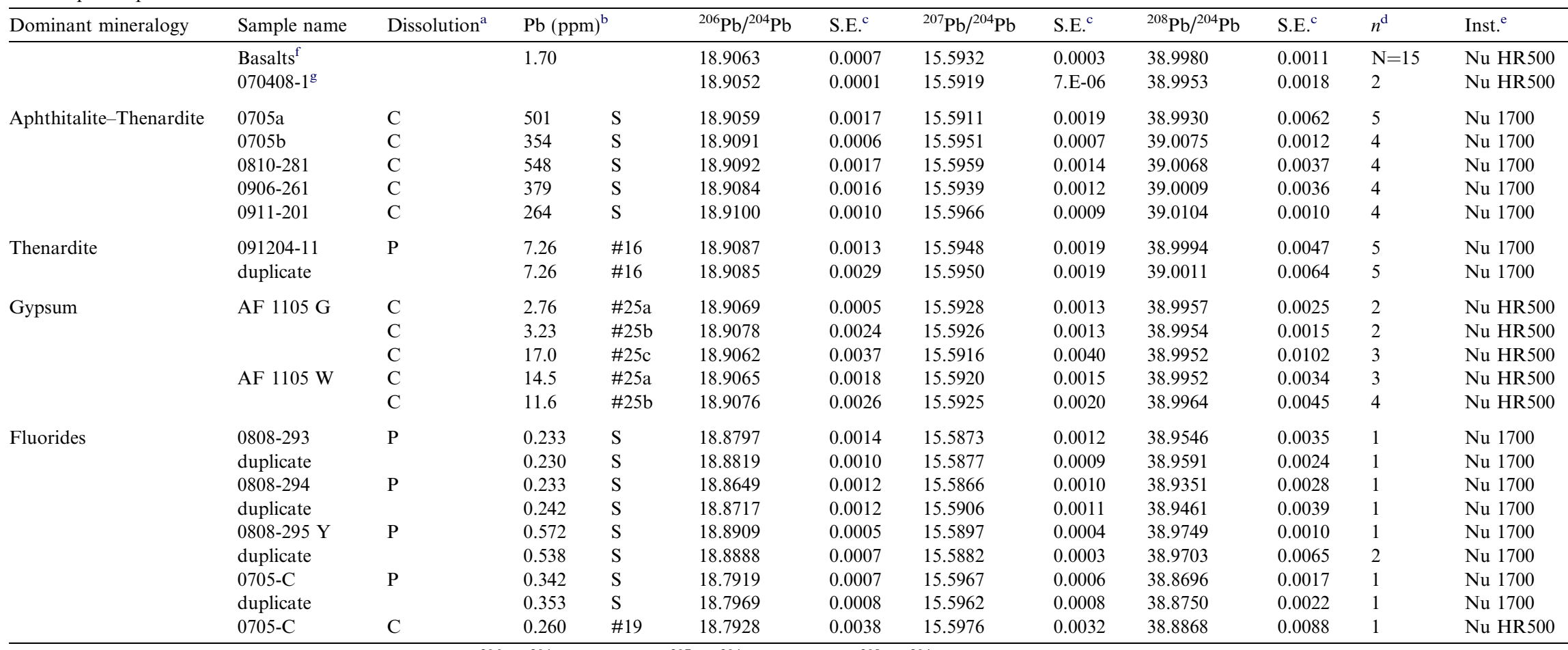

$\mathrm{Pb}$ isotopic compositions are relative to NBS 981 values: ${ }^{206} \mathrm{~Pb} /{ }^{204} \mathrm{~Pb}=16.9356,{ }^{207} \mathrm{~Pb} /{ }^{204} \mathrm{~Pb}=15.4891,{ }^{208} \mathrm{~Pb} /{ }^{204} \mathrm{~Pb}=36.7006$.

$\mathrm{S}: \mathrm{Pb}$ concentration inferred from total $\mathrm{Pb}$ signal during MC-ICP-MS measurement.

\#: $\mathrm{Pb}$ and trace element concentrations measured on the same dissolution (see Supplementary Table B).

${ }^{a}$ C: Chip, P: powder.

$\mathrm{Pb}$ concentration data.

c Standard error of $\mathrm{n}$ analyses or within-run standard error when $n=1$.

${ }^{\mathrm{d}}$ Repeated analysis of the same solution or number of basalt samples analyzed $(\mathrm{N})$

e Instrument. Nu Plasma HR or Nu Plasma 1700 MC-ICPMS.

${ }^{\mathrm{f}}$ Mean composition of April 2007 lavas (15 samples). From Vlastélic et al. (2009a).

${ }^{g}$ Basalt sample re-analyzed. 


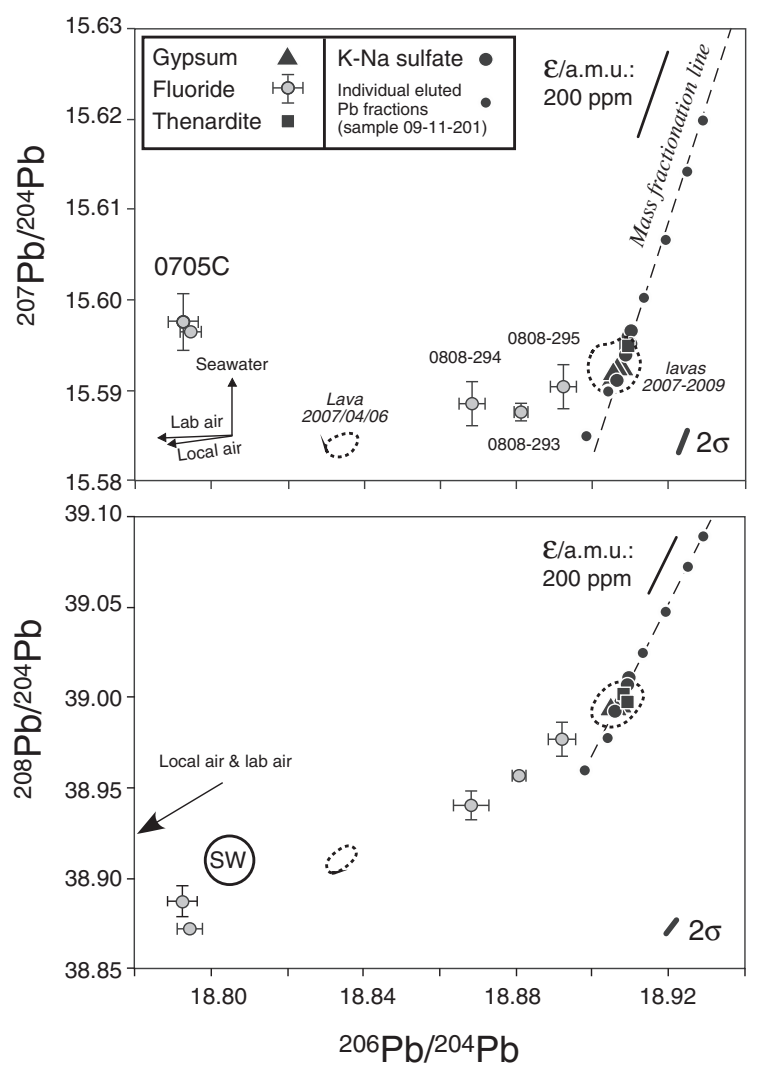

Fig. 6. Lead-lead isotope plots. The $\mathrm{Pb}$ isotope compositions of gas sublimates are compared to the signature of 2007-2009 lavas (dashed-outline white fields drawn using data from Vlastélic et al., 2009a). Compositions of individual $\mathrm{Pb}$ fractions collected during $\mathrm{Pb}$ elution on anionic resin are reported for sample 09-11-201 (data given in Table 3). These compositions plot along a mass-fractionation line (dashed line), where $\varepsilon$ denotes the mass fractionation factor per atomic mass unit (a.m.u.). Errors of individual data points ( $2 \sigma$ error inferred from duplicate analysis) as well as external error ( $2 \sigma$ reproducibility of NBS981) are shown. The composition of local seawater (SW) is shown in the ${ }^{208} \mathrm{~Pb} /{ }^{204} \mathrm{~Pb}$ vs. ${ }^{206} \mathrm{~Pb} /{ }^{204} \mathrm{~Pb}$ plot, whereas the vector toward seawater composition is shown in the ${ }^{207} \mathrm{~Pb} /{ }^{204} \mathrm{~Pb}$ vs. ${ }^{206} \mathrm{~Pb} /{ }^{204} \mathrm{~Pb}$ plot. Seawater composition is inferred from the average composition of $\mathrm{Fe}-\mathrm{Mn}$ crusts from the Madagascar basin $\left({ }^{206} \mathrm{~Pb} /{ }^{204} \mathrm{~Pb}=18.8052,{ }^{207} \mathrm{~Pb} /{ }^{204} \mathrm{~Pb}=15.6652\right.$ and ${ }^{208} \mathrm{~Pb} /{ }^{204} \mathrm{~Pb}=38.9103$ after renormalization to the NBS981 values used in this study) (Vlastélic et al., 2001). The vectors towards local air $\left({ }^{206} \mathrm{~Pb} /{ }^{204} \mathrm{~Pb}=16.49,{ }^{207} \mathrm{~Pb} /{ }^{204} \mathrm{~Pb}=15.47\right.$ and ${ }^{208} \mathrm{~Pb} /{ }^{204} \mathrm{~Pb}=36.20$, measured between 1994 and 1999 by Bollhöfer and Rosman (2000)) and laboratory air $\left({ }^{206} \mathrm{~Pb} /{ }^{204} \mathrm{~Pb}=17.440\right.$, ${ }^{207} \mathrm{~Pb} /{ }^{204} \mathrm{~Pb}=15.553$ and ${ }^{208} \mathrm{~Pb} /{ }^{204} \mathrm{~Pb}=37.386$ ), this work) are also shown.

field of lavas (Fig. 6 and 7a). There is less than 100 ppm difference between the average composition of sulfates and the average composition of lavas. Unlike lavas, sulfate samples plot along a mass discrimination line, with a total range of variation that does not exceed 110 ppm/a.m.u. As noted above, these data are expected to be highly precise because analyses were repeated up to five times (see Table 2). Statistical analysis of the bracketing NBS 981 standards reveals that it is theoretically possible to resolve very small isotope variations (Fig. 7b). For instance, a precision ( $2 \sigma$ error) of
60, 73 and $82 \mathrm{ppm}$ for ${ }^{206} \mathrm{~Pb} /{ }^{204} \mathrm{~Pb},{ }^{207} \mathrm{~Pb} /{ }^{204} \mathrm{~Pb}$ and ${ }^{208} \mathrm{~Pb} /{ }^{204} \mathrm{~Pb}$ ratios, respectively, is estimated for a sample that has been measured three times. The small variations of ${ }^{206} \mathrm{~Pb} /{ }^{204} \mathrm{~Pb},{ }^{207} \mathrm{~Pb} /{ }^{204} \mathrm{~Pb}$ and ${ }^{208} \mathrm{~Pb} /{ }^{204} \mathrm{~Pb}$ within the sulfate group (212, 357 and $447 \mathrm{ppm}$, respectively) are thus barely outside instrumental error. However, an additional, not well-constrained error arises from the fractionation of $\mathrm{Pb}$ isotopes during chemical separation. As shown on Fig. 6, Pb isotope variations in individual eluted $\mathrm{Pb}$ fractions (sample 09-11-201) are between seven and eight times larger than those existing within the whole sulfate group. Isotopic bias resulting from near total $\mathrm{Pb}$ recovery $(>95 \%)$ must thus be evaluated.

\section{DISCUSSION}

\subsection{Pb isotope measurements: Error arising from chemical separation}

This study aimed at resolving very small isotopic differences between magmas and their gaseous products. We observed that partial extraction $(<50 \%)$ of $\mathrm{Pb}$ from fluoride samples dissolved using boric acid yields compositions that are tens of ppm/a.m.u. off the compositions measured after complete $\mathrm{Pb}$ recovery. While many studies have focused on high-precision $\mathrm{Pb}$ isotope measurement on MC-ICPMS, very few have addressed the issue of isotopic fractionation during chemical separation. Blichert-Toft et al. (2003) and Baker et al. (2004) reported mass-dependent fractionation of $\mathrm{Pb}$ isotopes upon elution of pure $\mathrm{Pb}$ (NBS 981 standard) on anion exchange resin (AG1-X8). Both studies found that light $\mathrm{Pb}$ isotopes are eluted first. Baker et al. (2004) found that $\mathrm{Pb}$ isotope ratios increase by $130-500$ ppm/a.m.u. across the elution peak, and that fractionation increases with column size $(100-500 \mu \mathrm{l})$ and decreasing acid molarity (8-6 M HCl). Blichert-Toft et al. (2003), who used a larger column $(1 \mathrm{ml})$ and weaker $\mathrm{HCl}$ normality $(2.5 \mathrm{M})$ reported fractionation of the order of $1000 \mathrm{ppm} / \mathrm{a} . \mathrm{m} . \mathrm{u}$. They also estimated the isotopic bias resulting from incomplete $\mathrm{Pb}$ recovery to ca. $-150 \mathrm{ppm} / \mathrm{a} . \mathrm{m} . \mathrm{u}$. for $50 \% \mathrm{~Pb}$ loss (loss of late eluting $\mathrm{Pb}$ ).

Our experiment with a natural sublimate sample (Fig. 3b) gives a fractionation of ca. 800 ppm/a.m.u across the elution peak (Table 3 ). It is clear that this value largely depends on our ability to collect and analyze the very first and very last nanograms of eluted $\mathrm{Pb}$. The isotopic bias resulting from loss of $\mathrm{Pb}$ has been estimated (Fig. 8) distinguishing loss of early (isotopically light) eluting $\mathrm{Pb}$ from loss of late (isotopically heavy) eluting $\mathrm{Pb}$. The bias ( $\pm 60-90$ ppm/a.m.u. for $50 \% \mathrm{~Pb}$ loss) is about half that predicted by Blichert-Toft et al. (2003). This difference may reflect the fact that this previous study used a larger column $(1 \mathrm{ml})$ and loaded and eluted $\mathrm{Pb}$ in the same acid $(2.5 \mathrm{M} \mathrm{HCl})$. Based on our estimation, the isotopic bias does not exceed 20 ppm/a.m.u. for $95 \% \mathrm{~Pb}$ recovery (the minimum yield used to validate our data).

Isotopic fractionation of $\mathrm{Pb}$ upon elution on anion exchange resin is a critical issue that deserves further attention, especially when samples with complex and/or variable matrix are analyzed. Attention must also be paid 
(a)

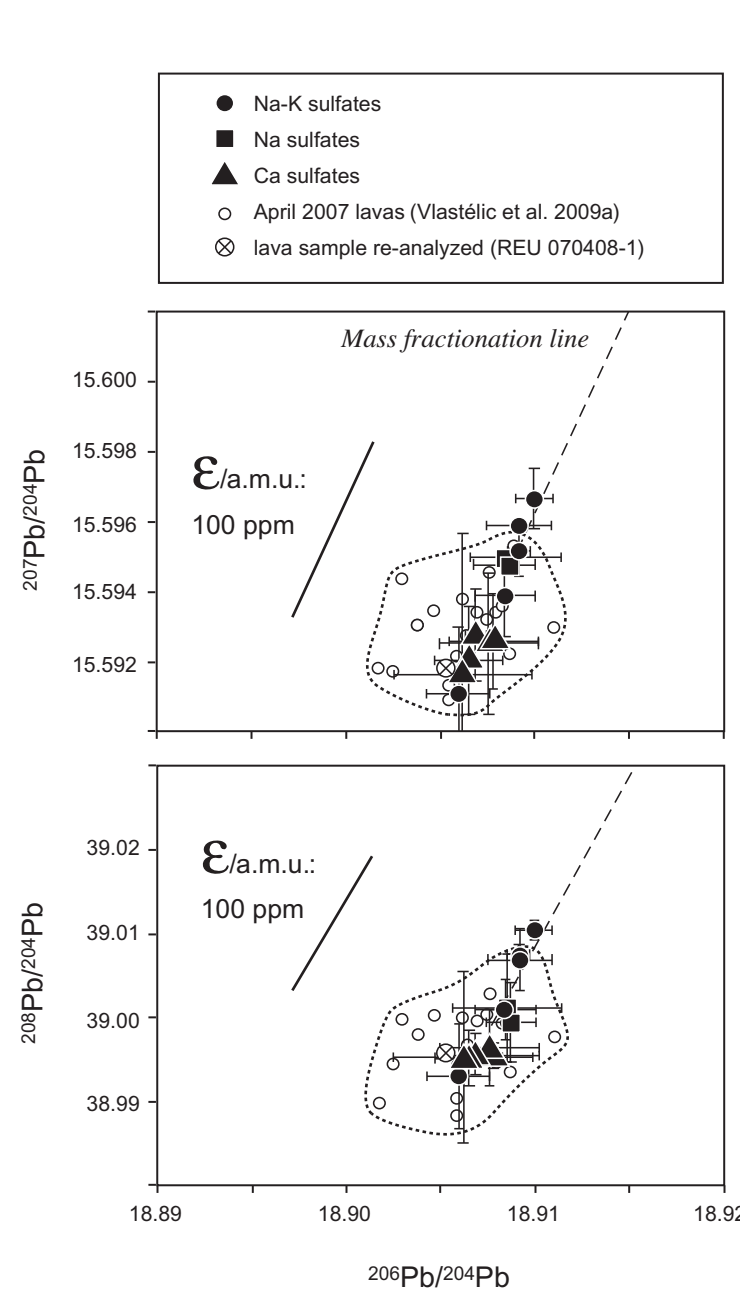

(b)
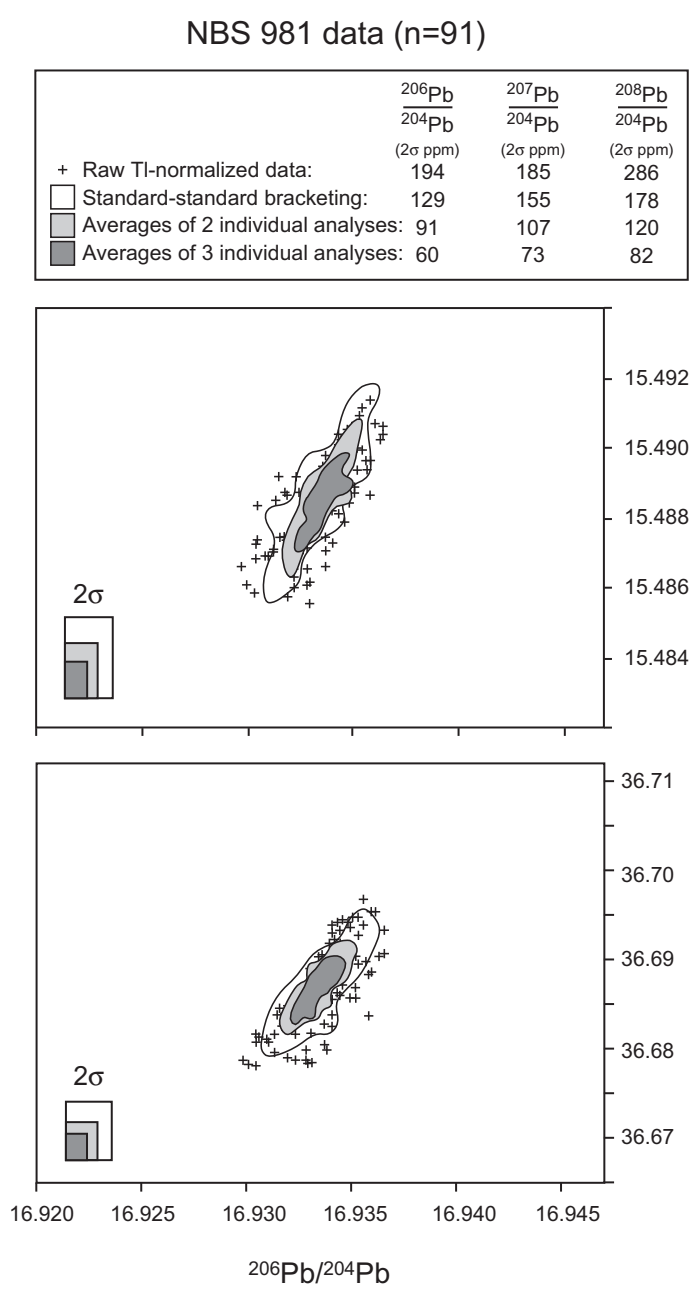

Fig. 7. Highlight on the small $\mathrm{Pb}$ isotope variations shown by sulfate samples. (a) The isotope signature of sulfate samples is compared to that of April 2007 lavas (individual data points from Vlastélic et al., 2009a). The composition of a lava sample (REU 070408-1) re-analyzed during the course of this study is also shown. The Pb-rich sublimate samples were repeatedly measured (up to six times, see Table 2) and average values are plotted here. The precision ( $2 \sigma$ error) of such repeated analyses was estimated from statistical analysis of the NBS 981 standard. Precision is shown as color-coded boxes on right panels (b) at a proportional scale: white box for samples measured once (lavas), light and dark gray boxes for samples measured two and three times, respectively (sublimates). (b) Reproducibility of the NBS 981 standard during the course of this study. Only standard analyses bracketing sample analyses are shown $(n=91)$. The relatively large scatter of the raw Tlnormalized data is due to shifts between sessions more than to drifts during individual sessions. In order to estimate the precision achieved when normalizing sample data to bracketing standards, we performed a standard-standard normalization test (i.e., normalizing oddnumbered standards to the bracketing even-numbered standards, and inversely). The resulting $2 \sigma$ dispersion (129, 155 and 178 ppm for ${ }^{206} \mathrm{~Pb} /{ }^{204} \mathrm{~Pb},{ }^{207} \mathrm{~Pb} /{ }^{204} \mathrm{~Pb}$ and ${ }^{208} \mathrm{~Pb} /{ }^{204} \mathrm{~Pb}$ ratios, respectively) is equivalent to the dispersion of raw Tl-normalized data at the scale of a $24 \mathrm{~h}$ measurement session. To estimate the precision one can expect from repeating sample analysis, averages of standard values randomly chosen are also plotted (average of two and average of three individual values). This shows that samples can be measured with a precision of $100 \mathrm{ppm}$ or better, provided that the amount of extracted $\mathrm{Pb}$ is high enough $(>80 \mathrm{ng})$ to allow repeated analysis. Plot scale is adjusted so that the reproducibility of standard data is directly comparable to the small isotope variations shown by samples (panel a).

to the dissolution step that may introduce anionic species, such as fluoborates, which may strongly alter the selective retention of $\mathrm{PbBr}_{3}^{-}$on anionic resin. Calibration of $\mathrm{Pb}$ chemistry with a natural sample representative of the studied sample suite is thus highly suitable. It is possible that less fractionation occurs when using the specific Sr-spec resin (Smet et al., 2010) or in the case of batch chemistry. Addition of a ${ }^{202} \mathrm{~Pb}-{ }^{205} \mathrm{~Pb}$ spike (Todt et al., 1996) at the dissolution step could be a simple way to correct for both chemical and instrumental $\mathrm{Pb}$ isotope fractionation.

\subsection{The absence of $\mathrm{Pb}$ isotope fractionation between sulfate deposits and lavas}

Fumarolic incrustations result from a suite a complex processes including high-temperature magma degassing, 
Table 3

$\mathrm{Pb}$ isotope composition of individual $\mathrm{Pb}$ fractions collected during elution of sample 09-11-201 on anionic resin.

\begin{tabular}{|c|c|c|c|c|c|c|c|c|c|}
\hline Fraction & $\mathrm{ng} \mathrm{Pb}^{\mathrm{a}}$ & $\% \mathrm{~Pb}$ eluted & ${ }^{206} \mathrm{~Pb} /{ }^{204} \mathrm{~Pb}$ & S.E. ${ }^{b}$ & ${ }^{207} \mathrm{~Pb} /{ }^{204} \mathrm{~Pb}$ & S.E. ${ }^{b}$ & ${ }^{208} \mathrm{~Pb} /{ }^{204} \mathrm{~Pb}$ & S.E. ${ }^{b}$ & $n^{\mathrm{c}}$ \\
\hline 1 & 25 & 0.2 & 18.8973 & 0.0013 & 15.5851 & 0.0011 & 38.9596 & 0.0027 & 1 \\
\hline 2 & 74 & 0.7 & 18.9037 & 0.0002 & 15.5901 & 0.0001 & 38.9776 & 0.0019 & 2 \\
\hline 3 & 3166 & 23.5 & 18.9072 & 0.0011 & 15.5929 & 0.0006 & 38.9959 & 0.0026 & 3 \\
\hline 4 & 6806 & 72.4 & 18.9085 & 0.0015 & 15.5950 & 0.0012 & 39.0052 & 0.0049 & 3 \\
\hline 5 & 2794 & 92.4 & 18.9129 & 0.0023 & 15.6004 & 0.0024 & 39.0243 & 0.0045 & 3 \\
\hline 6 & 800 & 98.2 & 18.9188 & 0.0015 & 15.6069 & 0.0010 & 39.0474 & 0.0048 & 3 \\
\hline 7 & 204 & 99.7 & 18.9244 & 0.0009 & 15.6143 & 0.0011 & 39.0722 & 0.0028 & 3 \\
\hline 8 & 47 & 100 & 18.9284 & 0.0007 & 15.6201 & 0.0006 & 39.0891 & 0.0017 & 1 \\
\hline
\end{tabular}

$\mathrm{Pb}$ isotopic compositions are relative to NBS 981 values: ${ }^{206} \mathrm{~Pb} /{ }^{204} \mathrm{~Pb}=16.9356,{ }^{207} \mathrm{~Pb} /{ }^{204} \mathrm{~Pb}=15.4891,{ }^{208} \mathrm{~Pb} /{ }^{204} \mathrm{~Pb}=36.7006$.

${ }^{a}$ Measured by ICP-MS.

${ }^{\mathrm{b}}$ Standard error of $n$ analyses or within-run standard error when $n=1$.

${ }^{c}$ Repeated analysis of the same solution.

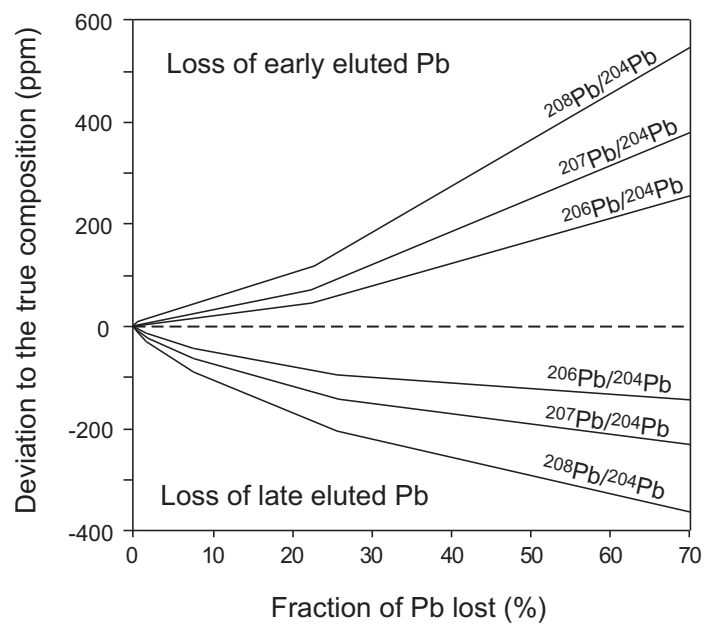

Fig. 8. Estimated isotopic bias resulting from partial $\mathrm{Pb}$ recovery during elution on anionic resin. The isotopic bias is estimated by integrating the isotopic ratios of individual $\mathrm{Pb}$ fractions up to a certain yield (see Table 3). Loss of early (isotopically light) eluting $\mathrm{Pb}$ is distinguished from loss of late (isotopically heavy) eluting $\mathrm{Pb}$. Note that the isotopic bias drastically increases when $\mathrm{Pb}$ loss exceeds $70 \%$ (not shown).

cooling and partial condensation of gas at fumarolic vents, and crystallization of sublimates. Additional processes such as interaction of volcanic gas with air, leaching of fumarole conduits by acidic condensates or meteoric water may also occur (Bernard and Le Guern, 1986; Symonds et al., 1992; Gilbert and Williams-Jones, 2008). Thermodynamic conditions required for sulfates formation are summarized in Getahun et al. (1996): sodium-potassium sulfates form when volcanic gas interacts with air, in particular at high gas/air ratios, while gypsum theoretically forms at low temperature $\left(125^{\circ} \mathrm{C}\right)$ and low gas/air ratios. Gypsum could be an hydration product of anhydrite $\left(\mathrm{CaSO}_{4}\right)$, which forms early $\left(710{ }^{\circ} \mathrm{C}\right)$ by reaction between gaseous $\mathrm{CaCl}_{2}$ and $\mathrm{SO}_{2}$. Alternatively, gypsum could also crystallize from condensed acid vapors having reacted with host rocks (Stoiber and Rose, 1974; Kodosky and Keskinen, 1990; Africano and Bernard, 2000).
In this context, the absence of significant isotopic fractionation of $\mathrm{Pb}$ between sulfate deposits and their genetic magmas is surprising. It is possible that the magnitude of isotopic fractionation within each individual process is extremely small yielding a net fractionation smaller than the precision of $\mathrm{Pb}$ isotope measurements. Although this hypothesis cannot be ruled out, it is not supported by the relatively large fractionation (permil level) of heavy isotopes expected from theoretical considerations (Schauble, 2007). In the following, we discuss how the isotopic composition of $\mathrm{Pb}$ could remain unchanged during degassing and condensation processes.

Diffusively driven fractionation of $\mathrm{Pb}$ isotopes is expected at the melt-gas interface. The composition of gaseous $\mathrm{Pb}$ matches the initial magma composition in the case of late-stage (ca. two thirds) fractional degassing or complete batch degassing (Fig. 9a). Both conditions are highly unrealistic because $\mathrm{Pb}$ is moderately volatile only. For an emanation coefficient of $\mathrm{Pb}$ in the order of $1 \%$ (Rubin, 1997), the net isotope fractionation is very close to the instantaneous fractionation factor $\left(\alpha_{\mathrm{vol}}^{20 X / 204}=\right.$ $\left({ }^{20 X} \mathrm{~Pb} /{ }^{204} \mathrm{~Pb}\right)_{\text {gas }} /\left({ }^{20 X} \mathrm{~Pb} /{ }^{204} \mathrm{~Pb}\right)_{\text {solid }}$, with $\left.X=6,7,8\right)$. Thus, gaseous $\mathrm{Pb}$ will remain isotopically unfractionated with respect to magmas only if $\alpha_{\mathrm{vol}} \sim 1$.

Isotopic fractionation as gas mixes with air, cools and partially condenses is more likely especially as stable isotope fractionation is enhanced at low temperature. Fractionation arises from change in coordination chemistry (e.g., number and nature of ligands) and/or oxidation state of $\mathrm{Pb}$ (Schauble, 2004, 2007). It is expected that equilibrium reactions between major $\left(\mathrm{PbCl}_{2}\right)$ and minor $\left(\mathrm{PbCl}_{4}, \mathrm{PbS}\right.$, $\mathrm{PbCl}, \mathrm{Pb}, \mathrm{PbBr}$ ) gaseous compounds of $\mathrm{Pb}$ (Symonds et al., 1992) lead to complex isotope fractionation in the gas phase. However, the isotopic evolution of the bulk gas phase is driven by $\mathrm{Pb}$ condensation. Gaseous $\mathrm{Pb}$ may condense as sulfide or chloride but, in both cases, the ultimate solid product in oxidizing conditions is $\mathrm{Pb}$ sulfate $\left(\mathrm{PbSO}_{4}\right)$ (Oskarsson, 1981; Bernard and Le Guern, 1986). As shown on Fig. 9b, the composition of the accumulated condensate, best representing our samples, evolves towards the initial composition of the gas as the fraction of $\mathrm{Pb}$ condensed increases. Assuming the primitive gas has the same composition as lavas (i.e. $\alpha_{\mathrm{vol}}=1$ ), the small isotopic range 
(a)

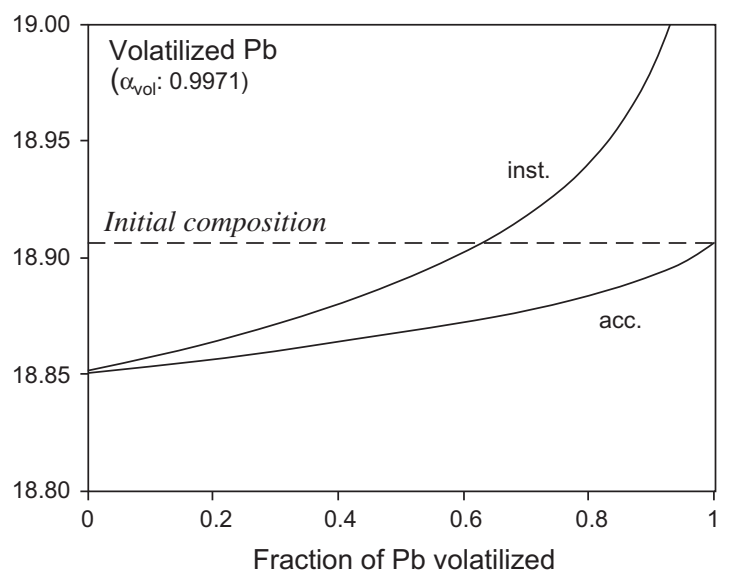

(b)

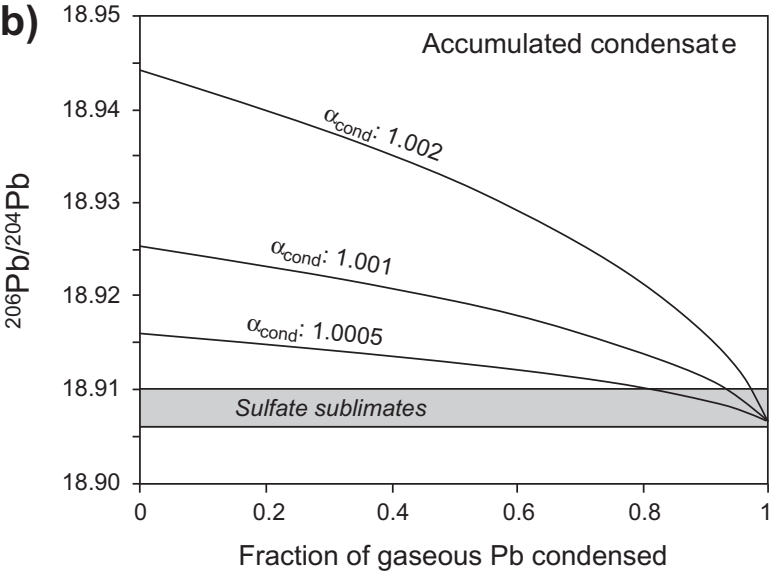

Fig. 9. Theoretical fractionation of $\mathrm{Pb}$ isotopes during volatilization and condensation. (a) Evolution of ${ }^{206} \mathrm{~Pb} /{ }^{204} \mathrm{~Pb}$ of the gas phase as a function of the fraction of $\mathrm{Pb}$ volatilized. The instantaneous (inst.) composition (fractional degassing) and the accumulated (acc.) composition (batch degassing) are given by $\left({ }^{206} \mathrm{~Pb} /{ }^{204} \mathrm{~Pb}\right)_{\mathrm{g}}=\left({ }^{206-}\right.$ $\left.\mathrm{Pb} /{ }^{204} \mathrm{~Pb}\right)_{\mathrm{S}, 0} \cdot \mathrm{F}^{(\alpha \mathrm{vol}-1)}$ and $\left({ }^{206} \mathrm{~Pb} /{ }^{204} \mathrm{~Pb}\right)_{\mathrm{g}}=\left({ }^{206} \mathrm{~Pb} /{ }^{204} \mathrm{~Pb}\right)_{\mathrm{S}, 0} \cdot\left(1-\mathrm{F}^{\alpha}\right.$ $\left.{ }^{\mathrm{vol}}\right) /(1-\mathrm{F})$, respectively. These Rayleigh distillation equations relate the $\mathrm{Pb}$ composition of the gas $(\mathrm{g})$ to the initial (0) solid (s) composition, the fraction of $\mathrm{Pb}$ remaining in the solid $(\mathrm{F})$, and the fractionation factor between degassing magma and gas $\left(\alpha_{\mathrm{vol}}=\left({ }^{206-}\right.\right.$ $\left.\left.\mathrm{Pb} /{ }^{204} \mathrm{~Pb}\right)_{\mathrm{g}} /\left({ }^{206} \mathrm{~Pb} /{ }^{204} \mathrm{~Pb}\right)_{\mathrm{S}}\right)$. The curves are drawn using an initial ${ }^{206} \mathrm{~Pb} /{ }^{204} \mathrm{~Pb}$ ratio of 18.9063 (average composition of the April 2007 lavas) and $\alpha_{\mathrm{vol}}$ of 0.9971 , which is inferred from running the NBS981 standard at $1062{ }^{\circ} \mathrm{C}$ on a Thermal Ionization Mass Spectrometer (Doucelance and Manhès, 2001). Note that this value of $\alpha_{\mathrm{vol}}$ is intermediate between the kinetic value $\left(0.9951=\left(\mathrm{m}_{204} / \mathrm{m}_{206}\right)^{0.5}\right)$ and the value $(0.9996)$ inferred from heating $\mathrm{Pb}$ alloy at $650{ }^{\circ} \mathrm{C}$ in a furnace (Cui and $\mathrm{Wu}, 2011$ ). (b) Evolution of ${ }^{206} \mathrm{~Pb} /{ }^{204} \mathrm{~Pb}$ of the accumulated condensate as a function of the fraction of gaseous $\mathrm{Pb}$ condensed. $\quad\left({ }^{206} \mathrm{~Pb} /{ }^{204} \mathrm{~Pb}\right)_{\text {cond }}=\left({ }^{206} \mathrm{~Pb} /{ }^{204} \mathrm{~Pb}\right)_{\mathrm{g}, 0 .} \cdot\left(1-\mathrm{f}^{\text {ccond }}\right) /(1-\mathrm{f})$ where $\alpha_{\text {cond }}$ is the fractionation factor between gas and condensate $\left(\alpha_{\text {cond }}=\left({ }^{206} \mathrm{~Pb} /{ }^{204} \mathrm{~Pb}\right)_{\text {cond }} /\left({ }^{206} \mathrm{~Pb} /{ }^{204} \mathrm{~Pb}\right)_{\mathrm{g}}\right)$ and $\mathrm{f}$ the fraction of $\mathrm{Pb}$ remaining in the gas. The curves are drawn using an initial ${ }^{206} \mathrm{~Pb} /{ }^{204} \mathrm{~Pb}$ ratio of 18.9063 (average composition of the April 2007 lavas) and realistic values of $\alpha_{\text {cond }}$. The composition of sulfate sublimate (gray field) is reproduced only for extensive condensation $\left(>80 \%\right.$ for $\left.\alpha_{\text {cond }}>1.0005\right)$.

of sulfates is reproduced only for large condensing extents $\left(>80 \%\right.$ for $\left.\alpha_{\text {cond }}>1.0005\right)$. In summary, it is suggested that the absence of $\mathrm{Pb}$ isotope fractionation between sulfate deposits and lavas results first, from $\mathrm{Pb}$ volatilization with no significant isotopic fractionation, followed by extensive condensation of gaseous $\mathrm{Pb}$, with possibly significant isotopic fractionation.

\subsection{The low-temperature fluoride deposits}

Thermochemical data indicate that hygroscopic $\mathrm{H}_{2} \mathrm{SO}_{4}$ forms below $202{ }^{\circ} \mathrm{C}$ (Symonds et al., 1992). This hot solution may dissolve gaseous $\mathrm{HF}$ and $\mathrm{HCl}$, which normally condense at low temperature $\left(25^{\circ} \mathrm{C}\right)$. It is expected that the resulting acidic fluids (with $\mathrm{pH}$ of ca. 1.6) react with wall rocks, leaching major cations, and subsequently precipitate as secondary minerals such as ralstonite (Africano and Bernard, 2000). This scenario reasonably accounts for the occurrence of refractory elements in the low-temperature deposits. However, it does not explain the complex trace element patterns (Fig. 5d), which depend on several parameters including the initial composition of gas condensate, the ability of host-rock elements to dissolve into acidic fluids, and the selective co-precipitation of elements with fluorides (Yokoyama et al., 1999). The depletion of most volatile elements including $\mathrm{Pb}$ is not consistent with a simple dilution process, as evidenced by the enrichment in $\mathrm{Pd}$ and $\mathrm{Tl}$, but rather suggests that samples formed from an evolved gas, which had lost most of its moderately volatile elements during early stages of condensation. It is also possible that the crystallization of highly insoluble species at high temperature removes volatile elements early during the cooling history of fluids. For instance, the difference in solubility product between $\mathrm{PbSO}_{4}\left(1.6 \times 10^{-8}\right)$ and $\mathrm{PbF}_{2}\left(2.7 \times 10^{-8}\right)$ suggests that $\mathrm{PbSO}_{4}$ crystallizes first, leaving behind a residual fluid depleted in $\mathrm{Pb}$.

Fluoride samples (with the exception of sample 0705C) have distinctly less radiogenic $\mathrm{Pb}$ compared to the bulk of the April 2007 lava flow (Fig. 6). Contamination by an external component is not supported by $\mathrm{Sr}$ and $\mathrm{Nd}$ isotope compositions, which are indistinguishable from those of lavas (see Supplementary Table B). Instead, the $\mathrm{Pb}$ isotope shift seems to be due to the incorporation of the same unradiogenic $\mathrm{Pb}$ component as that present in a lava sample erupted during the paroxysmal phase (April 6th) of the eruption of April 2007. The anomalous composition of this lava sample was ascribed to the entrainment of dense $\mathrm{Pb}$-rich phases (e.g., sulfides) by fast rising magmas (Vlastélic et al., 2009a). These phases have not been confidently identified yet, but their ubiquitous presence in high-flux eruptions is strongly supported by the frequent occurrence of unradiogenic anomalies in the erupted lavas $\left({ }^{206} \mathrm{~Pb} /{ }^{204} \mathrm{~Pb}\right.$ ratio down to 17.3) (Vlastélic, 2008). Preferential leaching of such phases by acidic gas condensates could explain the unradiogenic isotopic signature of most fluoride samples.

The anomalous ${ }^{207} \mathrm{~Pb} /{ }^{204} \mathrm{~Pb}$ ratio of sample $0705 \mathrm{C}$ cannot be explained by a mass-dependent shift of a composition initially plotting on the lava array. In the simplest case, this sample has been contaminated by seawater brines, which have highly radiogenic ${ }^{207} \mathrm{~Pb} /{ }^{204} \mathrm{~Pb}(\geqslant 15.66)$, but ${ }^{206} \mathrm{~Pb} /{ }^{204-}$ $\mathrm{Pb}$ and ${ }^{208} \mathrm{~Pb} /{ }^{204} \mathrm{~Pb}$ not very different from lavas (Vlastélic et al., 2001) (Fig. 6). Alternatively, the end-member trace 
element content (lowest $\mathrm{Ti}, \mathrm{Sc}, \mathrm{V}, \mathrm{Ba}$ and $\mathrm{Hf}$ content) of this sample suggests formation under unusual conditions or difference in mineralogy. Fractionation of odd and even-numbered isotopes of heavy elements could be mass-independent when driven by nuclear volume effects, which tend to concentrate heavy isotopes in compounds with low electron density at the nucleus (Schauble, 2007). Nuclear volume isotope fractionation is expected when $\mathrm{Pb}^{2+}$ (the most common valence state of $\mathrm{Pb}$ ) loses two s-electrons to form $\mathrm{Pb}^{4+}$, or when $\mathrm{Pb}$ forms bonds with elements with high electronegativity, such as F. One of these conditions could have been exceptionally fulfilled in sample $0705 \mathrm{C}$.

\subsection{Implications}

Given the intrinsic limits of the sample suite, it is difficult to reconstruct the whole history of $\mathrm{Pb}$ isotope fractionation during volatilization, gas condensation and sublimate crystallization, and thus to estimate the ultimate composition of volcanic emanations. It is clear that our preliminary results will have to be refined by more direct measurement of the gas phase, and their general applicability tested (e.g., their dependence on temperature, magma composition and volcanism type). Yet, some potential implications can be envisioned at this stage.

(1) The absence of net fractionation of $\mathrm{Pb}$ isotopes during sulfate formation is best explained by negligible isotope fractionation during $\mathrm{Pb}$ volatilization followed by extensive condensation of gaseous $\mathrm{Pb}$ (with possibly significant isotopic fractionation at that stage). This has two major implications. First, the amount of gaseous $\mathrm{Pb}$ escaping the fumarolic environment must be very small $(<10 \%)$ compared to the amount of $\mathrm{Pb}$ volatilized. This is probably true for both syn-eruptive and post-eruptive degassing, as our samples were formed in both conditions. Second, the corollary to extensive condensation is that the small fraction of $\mathrm{Pb}$ remaining in the gas phase should have an highly fractionated composition, which will be isotopically heavy or light depending on whether $\alpha_{\text {cond }}$ is less than unity or not.

(2) With the possible exception of sample $0705 \mathrm{C}$, the $\mathrm{Pb}$ isotope signature of the studied sublimates is not affected by contamination by external components, such as air or seawater brines, which have distinctive $\mathrm{Pb}$ isotopic signature (Bollhöfer and Rosman, 2000; Vlastélic et al., 2001). This suggests that the degassing system is relatively impervious to atmospheric and marine inputs. The absence of seawater contamination is also independently supported by $\mathrm{Sr}$ and $\mathrm{Li}$ isotope data.

(3) Sulfate sublimates, which concentrate $\mathrm{Pb}$, are highly soluble in water. This is particularly true for thenardite powder, which dissolves nearly instantaneously at ambient temperature. Most sub-aerial sublimates are thus very likely leached by rainwater soon after their formation, which explains the rare occurrence of pristine samples (sub-surface sublimates may have longer life depending on the permeability of the lava flows). Thus, in addition to non-condensable gases (Toutain et al., 2002) and rare volatile elements enriched in sublimates, runoff is also expected to entrain isotopically unfractionated $\mathrm{Pb}$ towards the hydrological system and seawater. This should be taken into account when tracking the source and the flux of $\mathrm{Pb}$ in the river and marine environments in the vicinity of active volcanoes.

(4) The $\mathrm{Pb}$ isotope composition of magmas erupted at active intraplate volcanoes (e.g., Hawaii, Réunion) fluctuates at short time-scales, typically between 1 and 10 years, most likely reflecting the cycling activity of magma chambers (Pietruszka and Garcia, 1999; Marske et al., 2007; Vlastélic et al., 2009a). The magnitude of these fluctuations (in the range of $10^{3}-10^{4} \mathrm{ppm}$ for ${ }^{206} \mathrm{~Pb} /{ }^{204} \mathrm{~Pb}$ ) is much larger than those resulting from magma degassing processes. The $\mathrm{Pb}$ isotope composition of primitive, high-temperature gas could thus be used to track change in magma composition at depth, and thus to anticipate events of magma recharge.

\section{CONCLUDING REMARKS}

This study aimed at detecting potential fractionation of $\mathrm{Pb}$ isotopes arising from degassing processes. With this respect, Piton de la Fournaise volcano is an ideal target since the $\mathrm{Pb}$ isotopic composition of erupted lavas is very precisely known. However, even in the most favorable case of post-eruptive degassing, such a fractionation is not identified confidently: sulfate samples with trace element patterns indicating relatively direct derivation from the gas phase display $\mathrm{Pb}$ isotopic compositions indistinguishable from their genetic lavas. It is possible that the magnitude of isotopic fractionation within each individual process that led to sulfates formation is extremely small yielding a net fractionation smaller than the precision of $\mathrm{Pb}$ isotope measurements (better than 60 ppm/a.m.u.). Alternatively, negligible isotope fractionation during $\mathrm{Pb}$ volatilization, followed by extensive condensation of gaseous $\mathrm{Pb}$, may also yield no net isotopic fractionation. Given the intrinsic limits of our sample suite, it is difficult to definitively resolve this issue here. However, the second scenario is preferred as it leaves open the possibility of significant isotopic fractionation during $\mathrm{Pb}$ condensation. It would imply that the amount of gaseous $\mathrm{Pb}$ escaping the fumarolic environment is small (most likely $<10 \%$ ) compared to the amount of $\mathrm{Pb}$ leaving magmas. As sulfate sublimates are highly soluble in water, condensed $\mathrm{Pb}$ will be entrained by runoff towards the hydrological system and seawater. On the other hand, distinctively less radiogenic $\mathrm{Pb}$ signatures characterize the low-temperature fluoride samples, whose trace element patterns record gas-rock interactions. Such compositions are ascribed to leaching ubiquitous unradiogenic phases (e.g., sulfides) by acidic gas condensates.

Resolving very small isotopic differences between magmas and their gaseous products remains an analytical challenge, which rests not only on instrumental performance 
but also on our ability to quantitatively recover $\mathrm{Pb}$ from samples with highly variable matrix and $\mathrm{Pb}$ content.

\section{ACKNOWLEDGEMENTS}

This paper benefited from the constructive comments of four anonymous reviewers and Ken Rubin. A reviewer is particularly thanked for pointing out the problem of $\mathrm{Pb}$ isotopic fractionation upon elution on columns. Thanks also to Frederic Moynier (Associate editor) who handled this manuscript as well as an earlier version. AF thanks particularly Eric Delcher and François Martel for their help in exploring the 2007 lava tubes. This work benefited from financial support from the CNRS (Institut National des Sciences de l'Univers) and the Agence Nationale de la Recherche (DEGAZMAG project, contract no. ANR 2011 Blanc SIMI 5-6 003). This is Laboratory of excellence ClerVolc contribution $\mathrm{n} 31$.

\section{APPENDIX A. SUPPLEMENTARY DATA}

Supplementary data associated with this article can be found, in the online version, at http://dx.doi.org/10.1016/ j.gca.2012.09.016.

\section{REFERENCES}

Africano F. and Bernard A. (2000) Acidic alteration in the fumarolic environment of Usu volcano, Hokkaido, Japan. $J$. Volcanol. Geotherm. Res. 97, 475-495.

Aki K. and Ferrazzini V. (2001) Comparison of Mount Etna, Kilauea, and Piton de la Fournaise by a quantitative modeling of their eruption histories. J. Geophys. Res. 106, 4091-4102.

Baker J., Peate D., Waight T. and Meyzen C. (2004) Pb isotopic analysis of standards and samples using a ${ }^{207} \mathrm{~Pb}-{ }^{204} \mathrm{~Pb}$ double spike and thallium to correct for mass bias with a doublefocusing MC-ICP-MS. Chem. Geol. 211, 275-303.

Baker R. G. A., Rehkämper M., Hinkley T. K., Nielsen S. G. and Toutain J.-P. (2009) Investigation of thallium fluxes from subaerial volcanism - Implication for the present and past mass balance of thallium in the oceans. Geochim. Cosmochim. Acta 73, 6340-6359.

Barde-Cabusson S., Finizola A., Peltier A., Chaput M., Taquet N., Dumont S., Duputel Z., Guy A., Mathieu L., Saumet S., Sorbadère F. and Vieille M. (2012) Structural control of collapse events inferred by self-potential mapping on the Piton de la Fournaise volcano (La Réunion Island). J. Volcanol. Geotherm. Res. 209-210, 9-18.

Battaglia J., Ferrazzini V., Staudacher T., Aki K. and Cheminée J.-L. (2005) Pre-eruptive migration of earthquakes at the Piton de la Fournaise volcano (Réunion Island). Geophys. J. Int. 161, 549-558.

Bernard A. and Le Guern F. (1986) Condensation of volatile elements in high-temperature gases of Mount St. Helens. $J$. Volcanol. Geotherm. Res. 28, 91-105.

Blichert-Toft J., Weis D., Maerschalk C., Agranier C. and Albarède F. (2003) Hawaiian hot spot dynamics as inferred from $\mathrm{Hf}$ and $\mathrm{Pb}$ isotope evolution of Mauna Kea volcano. Geochem. Geophys. Geosyst. 4, 8704. http://dx.doi.org/10:1029/ 2002GC000340.

Bollhöfer A. and Rosman K. J. R. (2000) Isotopic source signatures for atmospheric lead: The Southern Hemisphere. Geochim. Cosmochim. Acta 64, 3251-3262.

Budd P., Pollard A. M. and Scaife B. (1995) The possible fractionation of lead isotopes in ancient metallurgical processes. Archaeometry 37, 143-150.
Chugaev A. V., Yudovskaya M. A., Distler V. V., Chaplygin I. V. and Eremina A. V. (2007) Sources of ore-forming fluid in fumaroles of Kudryavy volcano, Kurile Islands: $\mathrm{Pb}$ isotopic composition of gas condensates and sublimate minerals. Dokl. Earth Sci. 413, 216-220.

Cui J. and Wu X. (2011) An experimental investigation on lead isotopic fractionation during metallurgical processes. Archaeometry 53, 205-214.

Doucelance R. and Manhès G. (2001) Reevaluation of precise lead isotope measurements by thermal ionization mass spectrometry: comparison with determinations by plasma source mass spectrometry. Chem. Geol. 176, 361-377.

Famin V., Welsch B., Okumura S., Bachèlery P. and Nakashima S. (2009) Three differentiation stages of a single magma at Piton de la Founaise volcano (Reunion hot spot). Geochem. Geophys. Geosyst. 10, Q01007. http://dx.doi.org/10.1029/2008GC002015.

Ferrara G., Garavelli A., Pinarelli L. and Vurro F. (1995) Lead isotope composition of the sublimates from the fumaroles of Vulcano (Aeolian Islands, Italy): Inferences on the deep fluid circulation. Bull. Volcanol. 56, 621-625.

Getahun A., Reed M. H. and Symonds R. (1996) Mount St. Augustine volcano fumarole wall rock alteration: mineralogy, zoning, composition and numerical models of its formation process. J. Volcanol. Geotherm. Res. 71, 73-107.

Gilbert C. D. and Williams-Jones A. E. (2008) Vapour transport of rare earth elements (REE) in volcanic gas: Evidence from encrustations at Oldoinyo Lengai. J. Volcanol. Geotherm. Res. 176, 519-528.

Houtermans F. G., Eberhardt P. and Ferrara G. (1964) Lead of volcanic origin. In Isotopic and Cosmic Chemistry (eds. H. Craig, S. Miller and C. J. Wasserburg). North-Holland, Amsterdam, pp. 233-243.

Jakobsson S.P., Leonardsen E.S., Balic-Zunic T. and Jonsson S.S. (2008) Encrustations from three recent volcanic eruptions in Iceland: The 1963-1967 Surtsey, the 1973 Eldfell and the 1991 Hekla eruptions. Fjölrit, Náttúrufrædistofnunar 52, pp. 65.

Kodosky L. and Keskinen M. (1990) Fumarole distribution, morphology, and encrustation mineralogy associated with the 1986 eruptive deposits of Mount St. Augustine, Alaska. Bull. Volcanol. 52, 175-185.

Kylander M. E., Klaminder J., Bindler R. and Weiss D. J. (2010) Natural lead isotope variations in the atmosphere. Earth Planet. Sci. Lett. 290, 44-53.

Lechler P. J. and Desilets M. O. (1990) Dissolution of native sulfur by acid bomb digestion technique for the determination of trace elements and total sulfur. Chem. Geol. 85, 305-309.

Lénat J.-F., Bachèlery P., Bonneville A., Tarits P., Cheminée J.-L. and Delorme H. (1989) The December 4, 1983 to February 18, 1984 eruption of Piton de la Fournaise (La Réunion, Indian Ocean): Description and interpretation. J. Volcanol. Geotherm. Res. 36, 87-112.

Lénat J.-F., Fitterman D., Jackson D. B. and Labazuy P. (2000) Geoelectrical structure of the central zone of Piton de la Fournaise volcano (Réunion). Bull. Volcanol. 62, 75-89.

Lindemann F. A. (1915) The Physical properties of isotopes. Nature 95, 7-8.

Lugmair G. W. and Galer S. J. G. (1992) Age and isotopic relationships among the angrites Lewis Cliff 86010 and Angra dos Reis. Geochim. Cosmochim. Acta 56, 1673-1694.

Marske J. P., Pietruszka A. J., Weis D., Garcia M. O. and Rhodes J. M. (2007) Rapid passage of a small-scale mantle heterogeneity through the melting regions of Kilauea and Mauna Loa Volcanoes. Earth Planet. Sci. Lett. 259, 34-50.

Mitolo D., Balić-Žunić T., Garavelli A., Acquafredda P., Leonardsen E. and Jakobsson S.P. (2010) $\mathrm{MgAlF}_{5} \cdot 1 \cdot 5 \mathrm{H}_{2} \mathrm{O}$ : A new phase from Eldfell volcano, Iceland. 89 Congresso SIMP. 
Moune S., Gauthier P.-J., Gislason S. R. and Sigmarsson O. (2006) Trace element degassing and enrichment in the eruptive plume of the 2000 eruption of Hekla volcano, Iceland. Geochim. Cosmochim. Acta 70, 461-479.

Nakamura E., Ishikawa T., Birck J.-L. and Allègre C. J. (1992) Precise boron isotopic analysis of natural rock samples using a boron-mannitol complex. Chem. Geol. 94, 193-204.

Nativel P. (1972) Découverte de thénardite dans les dépôts fumerolliens de la Fournaise (île de la Réunion). Bull. Soc. Fr. Minéral. Cristallogr. 95, 529-531.

Nercessian A., Hirn A., Lépine J.-C. and Sapin M. (1996) Internal structure of Piton de la Fournaise volcano from seismic wave propagation and earthquake distribution. J. Volcanol. Geotherm. Res. 70, 123-143.

Nonell A., Toutain J.-P., Polvé M., Munoz M. and Berger G. (2005) First coupled $\mathrm{Sr}$ and $\mathrm{Pb}$ isotopic measurements in volcanic gas condensates and groundwaters of Vulcano Island (Italy). Geochem. Geophys. Geosyst. 6, 11011. http://dx.doi.org/ 10:1029/2005GC000980.

Oskarsson N. (1981) The chemistry of Icelandic lava incrustations and the latest stages of degassing. J. Volcanol. Geotherm. Res. 10, 93-111.

Peltier A., Bachèlery P. and Staudacher T. (2009) Magma transport and storage at Piton de la Fournaise (La Réunion) between 1972 and 2007: A review of geophysical and geochemical data. J. Volcanol. Geotherm. Res. 184, 93-108.

Pietruszka A. J. and Garcia M. O. (1999) A rapid fluctuation in the mantle source and melting history of Kilauea volcano inferred from the geochemistry of its historical summit lavas (17901982). J. Petrol. 40, 1321-1342.

Rubin K. (1997) Degassing of metals and metalloids from erupting seamount and mid-ocean ridge volcanoes: Observations and predictions. Geochim. Cosmochim. Acta 61, 3525-3542.

Schauble E.A. (2004) Applying stable isotope fractionation theory to new systems. In: Geochemistry of non-traditional stable isotopes (eds. C.M. Johnson, B.L. Beard, F. Albarede). Rev. Mineral. Geochem. Mineral. Soc. Am., Geochem. Soc., 55, pp. $65-111$.

Schauble E. A. (2007) Role of nuclear volume in driving equilibrium stable isotope fractionation of mercury, thallium, and other very heavy elements. Geochim. Cosmochim. Acta 71, 2170-2189.

Smet I., De Muynck D., Vanhaecke F. and Elburg M. (2010) From volcanic rock powder to $\mathrm{Sr}$ and $\mathrm{Pb}$ isotope ratios: a fit-forpurpose procedure for multi-collector ICP-mass spectrometric analysis. J. Anal. At. Spectrom. 25, 1025-1032.

Staudacher T., Ferrazzini V., Peltier A., Kowalski P., Boissier P., Catherine P., Lauret F. and Massin F. (2009) The April 2007 eruption and the Dolomieu crater collapse, two major events at Piton de la Fournaise (La Réunion Island, Indian Ocean). $J$. Volcanol. Geotherm. Res. 184, 126-137.

Stoiber R. E. and Rose W. I. (1974) Fumarole incrustations at active Central American volcanoes. Geochim. Cosmochim. Acta 38, 495-516.

Strelow F. W. E. (1978) Distribution coefficients and anion exchange behavior of some elements in hydrobromic-nitric acid mixtures. Anal. Chem. 50, 1359-1361.

Symonds R. B., Reed M. H. and Rose W. I. (1992) Origin, speciation, and fluxes of trace-element gases at Augustine volcano, Alaska: Insight into magma degassing and fumarolic processes. Geochim. Cosmochim. Acta 56, 633-657.

Todt W., Cliff R. A., Hanser A. and Hofmann A. W. (1996) Evaluation of a ${ }^{202} \mathrm{~Pb}-{ }^{205} \mathrm{~Pb}$ double spike for high-precision lead isotope analysis, in Earth Processes. In Reading the Isotopic Code (eds. A. Basu and S. Hart). AGU, pp. 429-437.
Toutain J.-P. (1987) Contribution à l'étude des sublimés volcaniques. Minéralogie, géochimie, thermodynamique. Exemple du Momotombo, du Piton de la Fournaise et du Poas. Thesis, Université Pierre et Marie Curie, pp. 190.

Toutain J.-P. and Meyer G. (1989) Iridium-bearing sublimates at hot-spot volcano (Piton de la Fournaise, Indian Ocean). Geophys. Res. Lett. 16, 1391-1394.

Toutain J.-P., Aloupogiannis P., Delorme H., Person A., Blanc P. and Robaye G. (1990) Vapor deposition of trace elements from degassed basaltic lava, Piton de la Fournaise volcano, Reunion Island. J. Volcanol. Geotherm. Res. 40, 257-268.

Toutain J.-P., Baubron J.-C. and François L. (2002) Runoff control of soil degassing at an active volcano. The case of Piton de la Fournaise. Réunion Island. Earth Planet. Sci. Lett. 197, 83-94.

Toutain J.-P., Sonke J., Munoz M., Nonell A., Polvé M., Viers J., Freydier R., Sortino F., Joron J.-L. and Sumarti S. (2008) Evidence for $\mathrm{Zn}$ isotopic fractionation at Merapi volcano. Chem. Geol. 253, 74-82.

Vallelonga P. and Mather T. A. (2003) Lead ( $\mathrm{Pb}$ ) fluxes and $\mathrm{Pb}$ isotopic compositions from Masaya Volcano, Nicaragua. Atmos. Environ. 37, 4453-4460.

Violette S., Ledoux E., Goblet P. and Carbonnel J.-P. (1997) Hydrologic and thermal modeling of an active volcano: The Piton de la Fournaise, Reunion. J. Hydrol. 191, 37-63.

Vlastélic I. (2008) Unradiogenic $\mathrm{Pb}$ anomalies in historical lavas of Piton de la Fournaise (Reunion Island). Eos Trans. AGU 89, 53, Fall Meet Suppl., Abstract V43B-2153..

Vlastélic I., Abouchami W., Galer S. J. G. and Hofmann A. W. (2001) Geographic control on $\mathrm{Pb}$ isotopic distribution and sources in Indian Ocean Fe-Mn deposits. Geochim. Cosmochim. Acta 65, 4303-4319.

Vlastélic I., Deniel C., Bosq C., Télouk P., Boivin P., Bachèlery P., Famin V. and Staudacher T. (2009a) Pb isotope geochemistry of Piton de la Fournaise historical lavas. J. Volcanol. Geotherm. Res. 184, 63-78.

Vlastélic I., Koga K., Chauvel C., Jacques G. and Télouk P. (2009b) Survival of lithium isotopic heterogeneities in the mantle supported by HIMU-lavas from Rurutu Island, Austral Chain. Earth Planet. Sci. Lett. 286, 456-466.

White W. M., Albarède F. and Télouk P. (2000) High-precision analysis of $\mathrm{Pb}$ isotopic ratios by multi-collector ICP-MS. Chem. Geol. 167, 257-270.

Yokoyama T., Makishima A. and Nakamura E. (1999) Evaluation of the coprecipitation of incompatible trace elements with fluoride during silicate rock dissolution by acid digestion. Chem. Geol. 157, 175-187.

Yudovskaya M. A., Tessalina S., Distler V. V., Chaplygin I. V., Chugaev A. V. and Dikov Y. P. (2008) Behavior of highlysiderophile elements during magma degassing: A case study at the Kudryavy volcano. Chem. Geol. 248, 318-341.

\section{FURTHER READING}

Rehkämper M., Halliday A. N., Fitton J. G., Lee D.-C., Wieneke M. and Arndt N. T. (1999) Ir, Ru, Pt, and Pd in basalts and komatiites: New constraints for the geochemical behavior of the platinum-group elements in the mantle. Geochim. Cosmochim. Acta 63, 3915-3934.

Vlastélic I., Staudacher T., Bachèlery P., Télouk P., Neuville D. and Benbakkar M. (2011) Lithium isotope fractionation during magma degassing: constraints from silicic differentiates and natural gas condensates from Piton de la Fournaise volcano (Réunion Island). Chem. Geol. 284, 26-34.

Associate editor: Fred Moynier 